Vol. $30,1: 3-49,1985$

\title{
Fluctuations in an Island Bank Vole Population in the Light of the Study on its Organization ${ }^{1}$
}

\author{
Gabriela BUJALSKA
}

\begin{abstract}
Bujalska G., 1985: Fluctuations in an island bank vole population in the light of the study on its organization. Acta theriol., 30, 1: 3-49 [With 5 Tables \& 12 Figs.]

A long-term study on the demography of an island population of the bank vole, Clethrionomys glareolus (Schreber, 1780), provided a deeper insight into the mechanisms underlying number fluctuations, also reproduction rate and survival of different components of the population structure. Among these processes only reproduction was regulated, which stabilized population numbers during the breeding season. Survival, being subject to random factors (except for particularly low population densities), was a destabilizing process leading to number fluctuations. Based on the described relationships between reproduction and survival, on the one hand, and population numbers, on the other, a stepwise simulation was run for 55 years. The results of this empirical model were compared with field results. It has been pointed out that random changes in temperature and food conditions in spring generate a 2.6-year cycle, while 11-year cycle in these conditions generates an 11-year cycle of the bank vole numbers. The results are discussed against the background of recent concepts concerning population demography. It has been shown that number fluctuations should not always be identified with number regulation of the entire population, and that they need not be subject to densitydependent processes.
\end{abstract}

[Institute of Ecology PAS, Dziekanów. 05-092 Łomianki, Poland]

1. Introduction

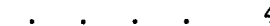

2. Methods of collecting, veryfying, and processing material . . . . . 5

2.1. Procedure of colleting material . . . . . . . . . . . . . 5

2.2. Important moments in the history of the study . . . . . . . 6

2.3. Estimation of population numbers . . . . . . . . . . . .

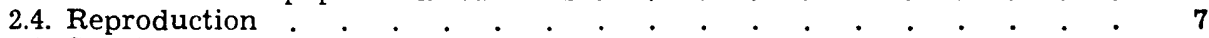

2.5. Survival . + . . . . . . . . . . . 9

2.6. Estimation of the standing crop biomass of the herb-layer . $\quad . \quad 9$

3. Results of the estimation of population parameters . . . . . . . . 9

3.1. Population size and its determinants . . . . . . . . . . . . . . . $\quad$. 9

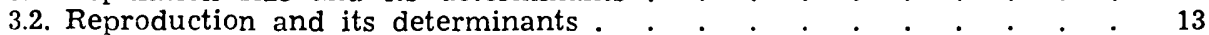

3.3. Survival and its determinants . . . . . . . . . . . . . . . . . 17

4. Description of the simulation model . . . . . . . . . . . . . 21

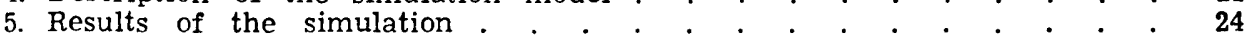

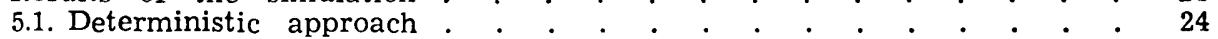

5.2. Probabilistic approach . . . . . . . . . . . . . . 27

5.3. Do population cyles exist in the bank vole? . . . . . . . . 31

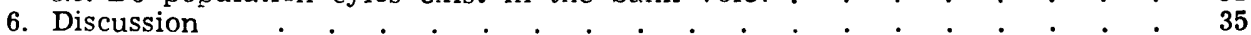

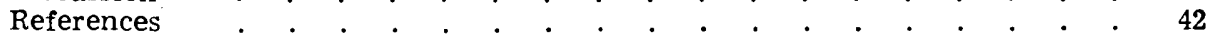

1 Praca wykonana w ramach problemu MR.II.15 koordynowanego przez Instytut Ekologii PAN. 


\section{INTRODUCTION}

Changes in the numbers of animal's, especially those belonging to species of economic importance, have attracted man's attention from the remotest times, long before techniques of number estimation were developed and the concept of outbreaks was introduced. At those times it was belived that God was responsible for everything. However, observation of the fate of animals and some philosophical generalizations (most clearly expressed by Isaac Bashevis Singer), tend to imply that God stopped interfering in the course of events once he had created the world. Thus, the animals themselves are responsible for their fates, and the patterns of their behaviour are called life strategies.

The basic concepts of modern ecological approaches that attempt to explain the underlying mechanisms of population dynamics centre upon two main lines of reasoning. The first one, represented by Thompson (1929) and Andrewartha and Birch (1954), stresses the role of environmental factors in shaping population dynamics. It includes limited resources, climatic conditions, or finite time for population growth. The second, developed by Nicholson (1933, 1954), Smith (1935) and Solomon (1949), relates changes in numbers to density-dependent changes in demographic processes damping down either increases or decreases in population numbers.

From the latter group of ideas stems Petrusewicz's (1966) concept that not all individual's are of equal importance with respect to their function in the population. Consequently, the population has a structure, and particular elements of this structure, which form a functional "organized" unity, are of crucial importance to population dynamics. According to this concept, population dynamics is an effect of many demographic processes (birth rate, death rate, migration) related to different elements of the whole structure and their interaction.

However, the traditional description of changes in population dynamics is reminiscent of the description of a vollcano, in terms of its shape, height, and so on. Such a description does not allow an understanding of the causes of such eruptions. To find these causes, one must go "inside". In the case of a population this seems to be to its organization.

In the present paper reproduction and survival in an island population of the bank vole Clethrionomys glareolus (Schreber, 1780) are analysed as a starting point for understanding the mechanisms underlying these two processes responsible for population dynamics. This population has been an object of many studies. Such problems as age structure (Gliwicz, 1975), sex ratio (Bujalska, 1984 a), spatial distribution (Bujal'ska, 1970, 1973, Mazurkiewicz, 1971), social structure (Rajska-Jurgiel, 1976), 
reproduction (Bujalska, 1970, 1973, 1975 a, 1984 b, 1985), and mortality (Bujalska, 1975 a, 1984 b, Gliwicz, 1975) were analysed. Using the results of these studies it was possible to prepare a partial synthesis in the form of a simulation model for changes in numbers. This model was based on the analysis of reproduction and mortality in the first half of the breeding season, that is, from April' to July (Bujalska, $1984 \mathrm{~b}$ ). This model implies that the processes occurring in the population over the first half of the breeding season tend to stabilize population numbers through damped oscillations, and the key role in the stabilization process is played by reproduction.

The objective of the present paper is to find the mechanisms determining reproduction and survival in the second half of the breeding season, and also survival in the postbreeding period (from October to April). It will be possible to develop an empirical model explaining seasonal dynamics of changes in numbers and also long-term dynamics on the basis of these mechanisms. A comparison of the results of the simulation with selected features of the original material will demonstrate a verification of the parameters and processes used in the model.

\section{METHODS OF COLLECTING, VERIFYING, AND PROCESSING MATERIAL}

\subsection{Procedure of Collecting Material}

The study was conducted in 1966-1970, 1972, and 1975-1980 on Crabapple Island, which is located on Beldany Lake in north-eastern Poland. Since this is a small 4-ha island it was possible to trap over its entire area, consequently, to capture all individuals of trapping age. Habitat conditions were considered as typical for this species (Pucek, 1983); the island is covered by a mixed deciduous forest with a dense herb layer.

Four plant communities were distinguished there: (1) Ciraeo-Alnetum Oberdorfer $1953(7 \%$ of the island surface area), (2) Frangulo-Salicetum Malc. 1929 $(15 \%)$, and Tilio-Carpinetum Traczyk 1962 in two subtypes - (3) Tilio-Carpinetum stachyetosum silvaticae $(35 \%)$ and (4) Tilio-Carpinetum typicum (42\%) (Traczyk, $1965,1970)$.

The entire island was covered evenly with 159 trap-sites $15 \mathrm{~m}$ apart. Each trap-site contained three live traps baited with oats. Traps were checked twice a day (at 7 a.m. and 7 p.m.). Individuals captured for the first time were individually marked by toe clipping. On each capture, number, sex, body weight and trap number were recorded. Vaginal smears were taken from all females with the perforate vaginal orifice to distinguish mature and immature individuals, and in the former category also pregnant and nonpregnant females (Bujalska, 1970). In males from 1975-1980 the position of testes was assessed to distinguish mature and immature individuals.

Each year, five one-week trapping censuses were conducted from the end of April to the end of October. Only from 1966-1970, did censuses last for 10-14 
days. Starting from the June census, all the newly captured individuals were assumed to have been born in the current breeding season, and they were clas. sified into four cohorts, depending on the date of their appearance (determined by the rhythm of successive censuses). This animals marked in June were included in cohort $K_{1}$, in July in $K_{2}$, in September in $K_{8}$, and in October in $K_{4}$. Individuals born in the preceding year (overwintered), which constituted the basic stock of the population, were classified as cohort $\mathrm{K}_{0}$. In some cases, cohorts $\mathrm{K}_{1}$ and $\mathrm{K}_{2}$ (born in the first half of the breeding season) were pooled, and also cohorts $\mathrm{K}_{3}$ and $\mathrm{K}_{4}$ (born in the second half of the breeding season) were pooled, and they were termed the spring and autumn generations, respectively (Adamczewska, 1961; Schwartz et al., 1963).

In 1975-1980, the herb layer was sampled during each census to estimate the biomass of the standing crops. In each of the four communities, 20 random samples were taken. A $0.1 \mathrm{~m}^{2}$ frame was used, within which the aboveground plant parts were clipped. Then, the material was dried to a constant weight and weighed to the nearest $0.1 \mathrm{~g}$.

In all the study years the mean minimum temperature at a height of $5 \mathrm{~cm}$ above the ground surface for ten-day periods were taken from meteorological station at Mikolajki, located $20 \mathrm{~km}$ from the study area.

The data collected in this way provided basic information on (1) the number of individuals captured per census, their age structure (overwintered animals and four current-year cohorts) and physiological structure (mature and immature males and females, pregnant and nonpregnant females), and (2) the standing crop biomass of the herb layer, the main food of the bank vole (Obrtel \& Holišova, 1974; Gębczyńska, 1983). Since further arguments are balsed on these data, it was necessary to verify them (sections $2.3-2.6$ ).

\subsection{Important Moments in the History of the Stady}

The study population derives from the several dozen individuals introduction in the summer 1965. These animals originated from the Białowieża National Park. They replaced the original bank vole population native to the island. Regular observations combined with some experiments were started in 1966.

In June of 1969 a removal experiment was conducted, in which $66 \%$ of females and $43 \%$ of males were removed, that is, $55 \%$ of the members of cohort $\mathrm{K}_{1}$. Since the population had already recovered by July (Bujalska, 1973), all information obtained in this year was included for further analysis.

In October of 1971, large amount of oats were supplied on the island, and since the oat losses were gradually replenished throughout 1972, thus the available food supply was increased. As a result, the onset of breeding in 1972 occurred earlier (mid-February), and an "additional" cohort was produced which, together with the overwintered animals, formed the breeding stock of the population in April (Bujalska, $1975 \mathrm{~b}$ ). Also the number of individuals increased (Bujalska, $1975 \mathrm{~b}$; Andrzejewski \& Mazurkiewicz, 1976), as well as the number of mature females (Bujalska, $1975 \mathrm{~b}$ ). This year is omitted from the analysis of the effect of natural food supply and temperature at the beginning of the growing season on population dynamics (simulation 2 in section 5.2.). This year was also excluded from the analysis in which the regression of the number of mature and pregnant females on population numbers was used (section 3 ).

In April of 1975, the population of Apodemus agrarius (the potential competitor) 
was removed after their introduction onto the island the previous year. As a result, the number of mature females was much higher, this being caused by changes in their spatial behaviour (Bujalska \& Janion, 1981). This year was excluded from the analyses based on the regression of the number of mature and pregnant females on population numbers (section 3.2.).

\subsection{Estimation of Population Numbers}

The number of individuals in the population was estimated using the method of the "common census". This method, based on the summation of the individuals recorded over the census period, is biased, as its results depend, for example, on the duration of the census. It may be expected that the longer the census, the higher the number estimated because new individuals are continuously being recruited into the trappable population fraction $(95 \%$ of the individuals recorded in a 14-day census were captured during the first 3 days of the census period).

In view of this, the "common census" method was compared with Jolly's (1965) method, which takes into consideration both the recruitment and mortality of trappable individuals. The results obtained by Jolly's method for 7- and 14-day censuses were regressed against the estimates obtained by the "common census" method. In both cases a linear function was found of the form $y=a+b x$. For the 7 day census it is described by the equation $y=4.275+0.981 x, r=+0.981$, $p<0.001$, and for the 14 -day census by the equation $y=1.264+0.903 x, r=+0.993$, $p<0.001$.

Since in both regressions the value of zero lies within one standard deviation of $a$ (intercept), the equation may be reduced to $y=b x$. In this equation $b$ totally defines the form of regression. For the 7-day censuses the equation is thus: $y=0.959 x, r=+0.962, p<0.001$, showing that the results of the "common census" are, on average $4.2 \%$ higher than those of the Jolly method. For 14-day censuses the relationship is $y=0.909 x, r=+0.986, p<0.001$. This equation implies that the overestimation of numbers is slightly higher here, namely, the estimates are higher by $10.1 \%$ as compared with the values obtained by the Jolly method.

Since most estimates were obtained from 7-day censuses and overestimation by the method of "common census" is insignificant for longer than 7-day censuses, this method was considered to be sufficiently accurate, and has been used for; further analyses.

The above results justify the assumption that the method of "common census" is also reliable when different components of the population are estimated, for example, the abundance of different age classes, or physiological groups.

\subsection{Reproduction}

In the study years, the breeding season extended from the beginning of April to September, as indicated by the observation of the dates of the first parturitions (in the second ten-day period of April) and last parturitions (extrapolated on the basis of pregnancy advancement during the Septemper census), around 1 October (Bujalska et al., 1968; Bujalska, 1970). Small several-day shifts in both dates were taken into account in the reproduction analyses for a given year (Bujalska, 1970). Only in 1972 (feeding experiment) the onset of breeding was as much as 6 weeks earlier (Bujalska, $1975 \mathrm{~b}$ ). Thus, fluctuations in the duration of the 
breeding season were not so pronounced as those observed by Zejda (1976) in Czechoslovakia.

A female was considered sexually mature if the perforation of vaginal entrance was combined with the presence of nucleated and cornified cells, or if a copulation plug was observed, or if she was pregnant. Vaginal perforation alone is not always a reliable indicator of puberty (Bujalska, 1970).

The number of pregnant females was estimated by the methods described by Bujalska (1970). The analysis of vaginal smears was supplemented by the observation of changes in body weight, noticeable signs of pregnancy, parturition in a trap, or the beginning of nursing.

The number born in time $t$ from the beginning of breeding up to 21 days preceding the end of the nearest census (in April), or from 20 days before the end of census $t-1$ to 21 days before the end of census $t$ (censuses in June, July, September, and October) were estimated from the formula (Bujalska et al., 1968):

$$
v_{t}=\frac{N P_{t} T_{t} L t}{\tau_{p}}
$$

where $\nu_{t}$ is the number born in time $t, N P_{t}$ is the number of pregnant females in time $t$, which has been obtained by a linear interpolation of the estimates from succesive censuses, $T_{t}$ is the length of reproduction period. Lt is the mean litter size in time $t$, and $\tau p$ is the mean duration of pregnancy in days. Data on seasonal variation in litter size were taken from Zejda (1966) and used as a basis for estimating the value of $L_{t}$ by linear interpolation. After Bujalska \& Ryszkowski (1966), $\tau$ p has been considered as a constant of 22 days.

The assumption that $L_{t}$ and $\tau_{p}$ are relatively fixed seems to be reasonable. According to the views of many authors, litter size varies little under specified ecological conditions. It varies more with latitude than with population density (Zejda, 1966). Even Ivanter's (1975) observations which suggest a tendency towards increasing litter size in low spring populations, which are increasing through autumn, do not show that the increased litter size stimulates a more rapid population growth.

Similarly, the duration of pregnancy, although variable to some extent (e.g. in relation to the number of embryos; Buchalczyk, 1970), is a relatively fixed parameter.

Only the value of $N P_{t}$ varies widely. Sviridenko (1967) has found that the proportion of pregnant females ranged from 20 to $60 \%$ of the mature females, and Bujalska et al. (1968) reported 20 to $96 \%$. Thus, it is at this point that one should look for functional relationships between reproduction and population dynamics.

It is also worth noting that the method for estimating the number of newborn applied here is biased due to the assumed continuity of giving birth. Each day a female gives birth to $1 / \tau_{p}$ litter, which in the event of her death overestimates the number of births (Bujalska, 1975 a).

The number of mature and immature males was estimated using a three-degree scale of testes position and size: (1) abdominal testes, (2) scrotal testes less than $1 \mathrm{~cm}$, and (3) scrotal testes more than $1 \mathrm{~cm}$ in size. Males of categories 2 and 3 were considered mature. Hence, the estimate of mature males can be overestimated due to those males of group 2 in which spermatogenesis has not yet begun. 


\subsection{Survival}

Survival of trappable and nontrappable parts of the population was estimated. To estimate the survival of nontrappable animals, the procedure described earlier was used (Bujalska et al., 1968, Bujalska, 1975 a). It is based on: (1) the division of the study period into about 6-week subperiods during which the individuals born could be trapped in the nearest census (that is, that they were born not later than 21 days prior to the end of this census), (2) the assumption, that the entire cohort (its size at the time of parturition is given by formula (1)) was born on the same day. This was the day on which $50 \%$ of the individuals of this cohort were born, and (3) the calculated number of survivors from the "day of birth". of the cohort to the last day of the census in which they were captured for the first time. Thus, the survival of nontrappable individuals is assessed as the proportion of individuals that survived during the first six weeks. Thus, the nontrappable population numbers comprise nestling (less than 21 day old) and newly weaned individuals which "waited" to the nearest census.

The survival of the trappable population members was caluclated as a difference in the number of individuals of a given category (or a cohort) in the periods between succesive censuses.

\subsection{Estimation of the Standing Crop Biomass of the Herb Layer}

The reliability of the method for the estimation of the herb layer biomass was checked. For this purpose, 50 samples were selected at random from all the samples collected, in the proportion corresponding to the size of the four forest habitats $(20$ samples from Tilio-Carpinetum typicum, 18 from Tilio-Carpinetum stachyetosum silvaticae, 8 from Frangulo-Salicetum, and 4 from Circaeo-Alnetum). Then, from the pool of 50 samples, subsamples were drawn with replacement and combined in larger "samples", the mean biomass of which was calculated. To estimate the significance of the difference between mean values of biomass in these "samples" a nonparametric Kruskal-Wallis test (one way ANOVA) was applied. This test has shown that there are significant differences between mean values from 10 "samples" made up of 5 subsamples each $(\mathrm{H}=18.11, \mathrm{df}=9, p<0.05)$, while there are no difference between mean value calculated for 10 "samples" composed of 10 subsamples each $(\mathrm{H}=16.30, \mathrm{df}=9, p>0.05)$. This result allows the assumption that the "sample" made up of only 10 subsamples taken by the stratified sampling method is sufficient to characterize the mean standing crop biomass of the herb layer. Thus, the applied "sample" size comprising 80 subsamples on each census was much higher than the minimum sample size required:

\section{RESULTS OF THE ESTIMATION OF POPULATION PARAMETERS}

\subsection{Population Size and its Determinants}

Population size showed seasonal changes. The lowest numbers were observed in April, when the population consisted only of overwintered animals. The highest numbers were noted in July (when so-called peak numbers occurred) or in September - October (in this case the number of animals gradually increased and no drastic reduction was recorded in the autumn) (Fig. 1). Using 12-year observation, it is not possible to 
state whether peak numbers occurred with a specific regularity, although the first five years of observation suggested a two-year cycle of numbers (Gliwicz, 1980).

There were also suggestions that the population size is little variable in spring (Petrusewicz et al., 1969, 1971). Further studies have shown, however, that numbers in April were the most variable of all the other months. It has been found that the coefficient of fluctuations CF (Whittaker, 1975), that is, $10^{\mathrm{Dl}}$ where $\mathrm{Dl}$ represents the standard deviations calculated for logarithms of population nos. over the 12-year study period, were 2.095 in April, whilst they were $1.852,1.515,1.454$, and 1.454 for June, July, Sept., and Oct. respectively (Bujalska, 1984 b). It has also

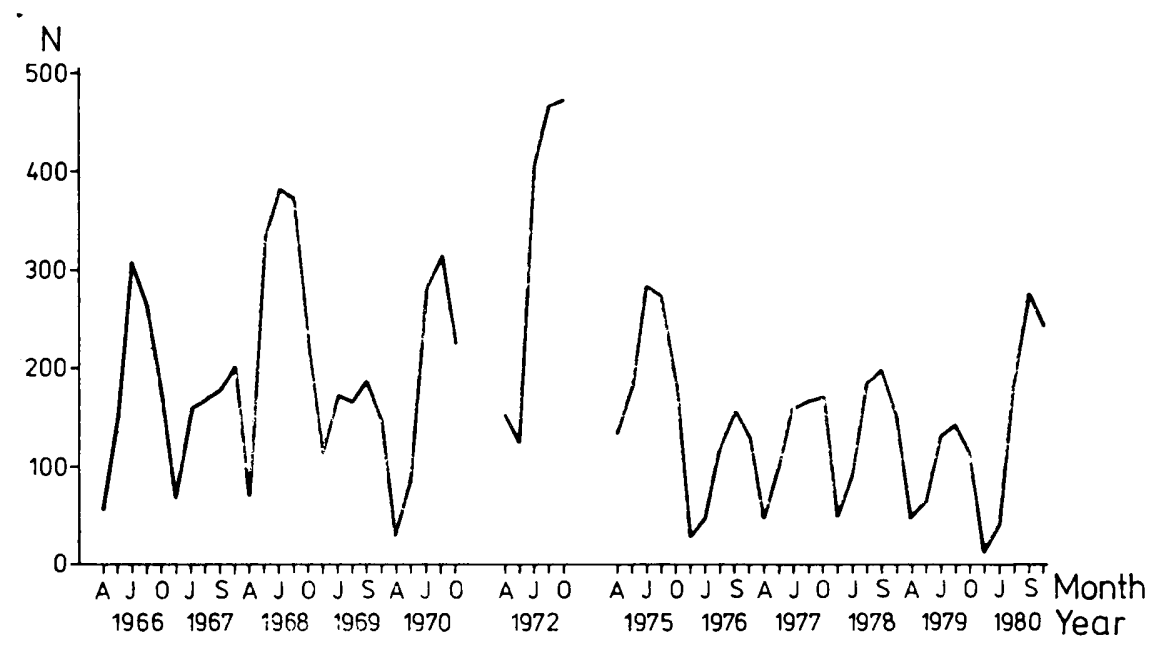

Fig. 1. Changes in population numbers (N) based on five censuses over the year. A - April, J - June, J - July, S - September, O - October.

been shown (Bujalska, $1984 \mathrm{~b}$ ) that it was predominantly food-climatic conditions which accounted for this great variability in early spring. Besides other facts reported in that paper, this thesis is illustrated by the relationship between the population size in April $(y)$ and the standing crop biomass of the herb layer in April $\left(x_{1}\right)$ and air temperature in the last ten-day period of April (that is, at the beginning of the growing season $\left(x_{2}\right)$ :

$$
\begin{gathered}
y=39.36+2.837 \cdot 10^{-14} x_{1}+1.068 x_{2} \\
R=0.998, \quad \mathrm{n}=5, \quad p<0.01
\end{gathered}
$$

Bujalska (1984 b) has pointed out that the population size in June, and to a lesser extent in July, was positively correlated with the pop- 
ulation size in April. No correlation was found between the population size in April and those in September and October.

These facts, combined with the analysis of the population growth rate in the periods between two censuses provided a basis for the conclusion that the damping of fluctuations in numbers occurs in the period June-July. At that time the population growth rate is curvilinear: it is high at a low initial population and gradually declines when numbers are higher at the beginning of the breeding season (in the period AprilJune, population growth rate is a linear function of the numbers in April (Bujalska, 1984 b)).

No relationship was found between population numbers in the censuses from June to October and the biomass of the herb layer. It has been found, instead, that numbers in September and October were positively correlated with numbers in July $(r=+0.93, p<0.001$ and $r=+0.71, p=0.01$, respectively). It may thus be expected that no great changes in numbers will occur in the second half of the breeding season; numbers in September and October are merely a simple linear function of population numbers in July, and the amplitude of fluctuations (CF) is relatively small.

However, numbers in October determine to some extent population size in April of the following year. A regression describing this relationships is of the form:

$$
\begin{gathered}
y=-16.12+0.37 x \\
r=+0.654, \quad p<0.05
\end{gathered}
$$

Although the determination coefficient is not higher than $43 \%$, it is difficult to neglect the importance of numbers in autumn after the end of the breeding season to the breeding stock of the population.

The relationship describing the effect of population numbers in October $\left(x_{1}\right)$ and the herb layer biomass $\left(x_{2}\right)$, on the population size in April of the following year $(y)$ is of the form:

$$
\begin{gathered}
y=12.27-0.12 x_{1}+0.131 x_{2} \\
R=0.998, \quad p<0.001
\end{gathered}
$$

Thus, it seems to describe well factors determining population size at the beginning of the breeding season (Bujalska, $1984 \mathrm{~b}$ ).

Then the goodness of fit of the distribution of population size to the normal distribution was analysed for each month (April, June, July, September, and October) over all the study years. As the sample size was small $(n=12)$, the method of linear regression of ranked normal deviates on population numbers was used (Sokal \& Rohlf, 1981). According to this method, the line of regression is calculated using eight 
central values of the population numbers, without the two extreme values from each end (33\% of the sample size), that is, the smallest and the largest. In this method, like in the graphical method of plotting frequencies in class intervals on so-called "probability paper", it is expected that all numbers of the sample will lie on the regression line if they fit the normal distribution. Deviations from the line of the regression have a similar interpretation. The test $D$ of Kolmogorov-Smirnov was used to evaluate the statistical fit of those numbers from the sample to the normal distribution.

Although the empirical distributions were not significantly different from the normal distribution in any one month $(p>0.2)$, the scatter of
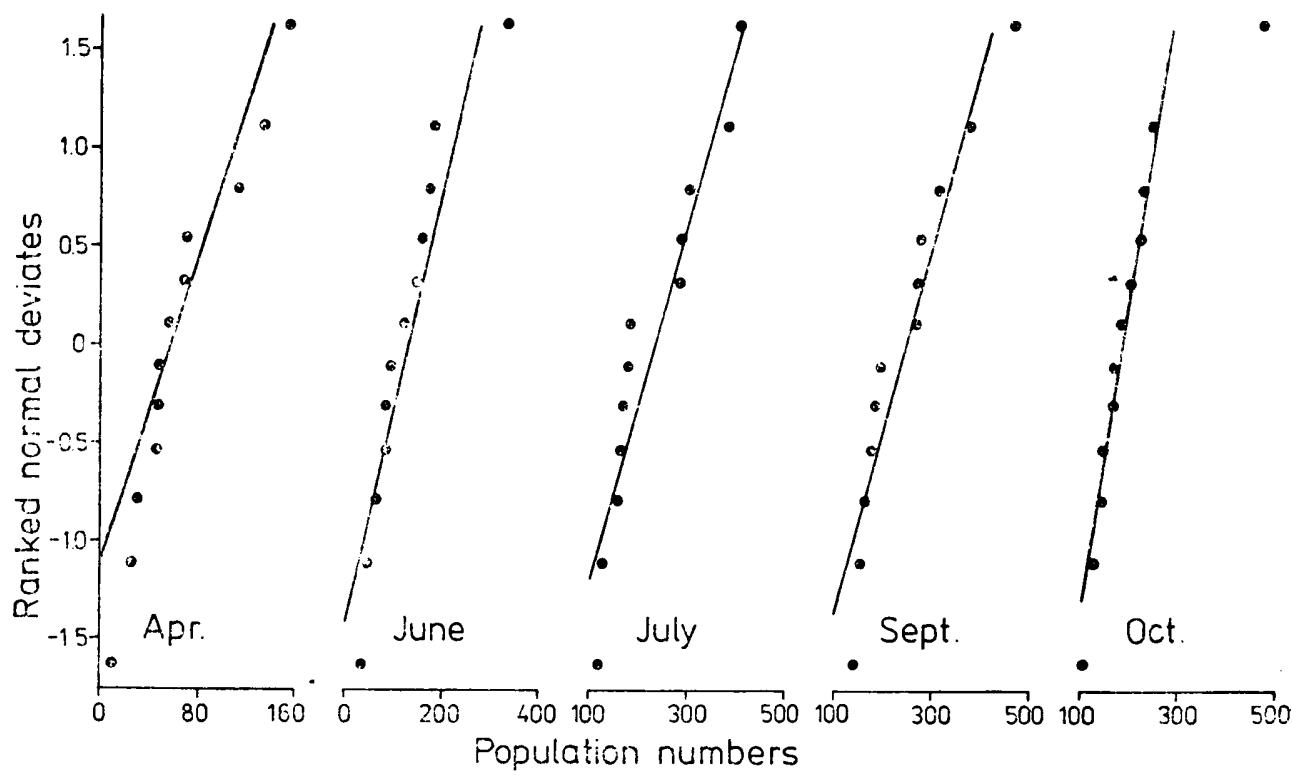

Fig. 2. Deviation from the normal distribution of empirical population numbers, as revealed by the ranked method for small samples. Solid line shows linear: regressions calculated for 8 central empirical values. Closed circles denote empirical data.

the points seems to suggest that: in April' the distribution tended to be skewed to the right or showed leptokurtosis; in June, September, and October there was a tendency to skewness to the right; in July to platykurtosis or to skewness to the right (Fig. 2).

Thus, three periods can be distinguished in the population fluctuations: (1) the most dynamic period in April-July, when intrapopulation mechanisms first cause an increase in numbers and then reduce the 
amplitude of fluctuations (stabilization), (2) the period July-October when earlier stabilized numbers are maintained; it is characterized by a certain inertia, and (3) the period October-April, also inert to some extent, in which the most violent changes are likely to occur at the beginning of the breeding period, when variable food conditions (determined in turn by climatic conditions) determine the size of the breeding stock, and, consequently, the rate of population growth in period (1). Each of these periods is characterized by differential population processes and differential underlying mechanisms.

It seems that to understand demographic processes, it may be useful to rank the parameters determining these processes with respect to population numbers, even if it is not assumed that these are density-dependent parameters in cause-and-effect terms. Since migration is not possible, the processes shaping the size of this island population can only involve reproduction and mortality.

\subsection{Reproduction and its Determinants}

In this paper only females are considered as responsible for reproduction. The reasons were that: (1) the entire process of reproduction, in the period before and after parturition, is modified by many physiological and ecological factors. The evidence for this is provided by many observations of maturation, oestrous cycle, copulation, fertilization, and pregnancy. In each of these stages the female is vulnerable to environmental stresses that can inhibit any of these stages. This is a clue for an observer that primarily breeding females depend in many ways on their ecological environment. In males the route from the attainment of sexual maturity to fertilization is much shorter, and hence the role of males is mainly limited to acquiring an oestrous female. (2) Reproduction, which is finalized by recruitment of new individuals into the population, also extends over the period of lactation (nursing), which is performed by females. In the polygamic voles one can not expect males to take care of the young (Zeveloff \& Boyce, 1980). In this difficult period, mostly due to the increased costs of maintenance (Kaczmarski, 1966), the breeding success depends upon the fate of the females. And (3) in females many important mechanisms determining the course of reproduction have been identified and described, which in the language of mathematical modelling means that there are available a provision of specified regressions. Paraphrasing what Krebs and Myers (1974) said, and relating this to the bank vole, one may say: so little is known of the behaviour of males... and about their role in shaping population dynamics.

The analysis concerns the potential reproduction, as expressed by 
the number of mature females, and the actual reproduction, as measured by the number of pregnant females (Bujalska, 1970).

The number of mature females recorded on successive censuses was plotted against the population density. Over the entire range of observed changes in the population density, the number of mature females is given by the equation (Bujalska, $1984 \mathrm{~b}$ ):

$$
\begin{aligned}
& N M_{t}=\sqrt{-840.63+35.91 N_{t}-0.0738 N t^{2}} \\
& R=0.875, \quad p<0.001
\end{aligned}
$$

where $N M_{t}$ it the number of mature females in time $t$, and $N_{t}$ is the population density in time $t$.

This function indicates that the rate of maturation declines when a certain critical population size is exceeded (about 120 individuals), and

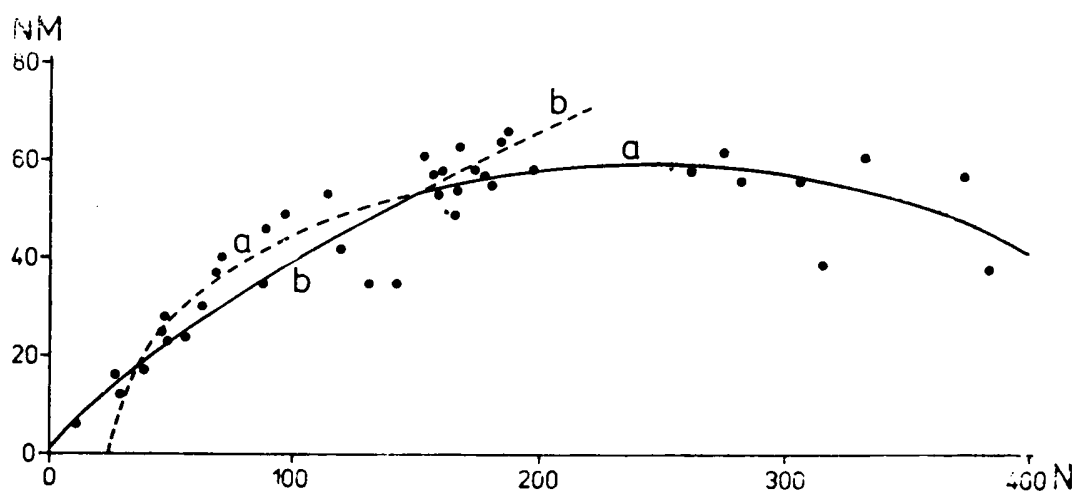

Fig. 3. The number of mature females (NM) plotted against the population numbers (N). Solid line denotes sections of the curves considered to fit the empirical data. Closed circles represent empirical data. a - the curve calculated from equation (2), $\mathrm{b}-$ the curve calculated from equation (3).

then the number of mature females is maintained at a relatively fixed level until the population density reaches the next critical value (more than 300 individuals), this being followed by a decrease in the number of mature females (Fig. 3).

Although equation (2) fits well empirical data within the range of numbers corresponding to the phase of relatively stabilized numbers of mature females, it does not seem to be useful to interpolation of the number of mature females in the range of small population numbers (e.g. for a population made up of 20 individuals the number of mature females would be zero). For this purpose it is better to use a power regression of the form: 


$$
\begin{gathered}
N M_{t}=1.294 N t^{0,750} \\
r=+0.995, \quad \mathrm{n}=32, \quad p<0.001
\end{gathered}
$$

where $N M_{t}$ and $N_{t}$ as in equation (2). This equation can be used to estimate the expected number of femal'es when $N_{t}<150$. For $N_{t} \cong 150$ the curves described by the equations (2) and (3) intersect.

By both approaches, three phases of changes in the number of mature females can be distinguished: (1) at low population densities $(<30 /$ ha) a rapid increase in the number of mature females. This situation mostly occurs at the onset of the breeding season, when the population consists either only of overwintered animals or also of young individuals belonging to the first spring cohort $\mathrm{K}_{1}$, which are recruited gradually as they emerge from their nests (the mean timing of their birth falls in early May). (2) At mean population densities, ranging from 30 to 80 individuals/ ha, the number of mature females is stabile. This can be observed in June-September in the years with no peak numbers. This implies that the rate of reproduction and consequently the growth rate of population are reduced, and (3) at high population densities (of the order of 100 and more individuals/ha) when peak numbers are reached in July, the number of mature females declines. This is due not only to a reduced rate of sexual maturation but also to the exclusion of mature females from reproduction (a situation similar to the winter anoestrous), which produced offspring at lower densities (Bujalska, 1970).

The mechanism stabilizing the number of mature females (and thus al'so the rate of maturation) consists of territorial tendencies of mature females, as has already been shown by an analysis of the spatial distribution (Bujalska, 1970) and also experimentally (Bujalska, 1973). These empirical results were then used as a basis for a simulation model in which territorial tendencies of mature females were assumed (Bujalska, 1985). The results of the simulation fully confirm the earlier view. Moreover, they indicate that the mechanism limiting the number of mature females can operate not only within this category of individuals. But it can also affect relationships between mature and immature females. This mechanism, which involves competition for retaining or acquiring the status of mature female, can reduce the number of mature females when the number of all females exceeds a certain level (Bujalska, 1985).

Then the actual reproduction was analysed. The numbers of pregnant females were regressed against population numbers. In April and June, this regression is described by a function analogical to that describing the relationship between the number of mature females and population numbers (Fig. 4), as the number of pregnant females in April and June 
is equal to or only slightly lower than the number of mature females. The equation is:

$$
\begin{aligned}
& N P_{t}=\longdiv { - 1 5 9 . 4 6 + 1 4 . 0 9 7 N _ { t } - 0 . 2 4 3 N t ^ { 2 } } \\
& R=0.774, \quad \mathrm{n}=24, \quad \mathrm{~F}=15.68, \quad p<0.001,
\end{aligned}
$$

where $N P_{t}$ is the number of pregnant females in time $t$, and $N_{t}$ as in equation (2). The above function, described by Bujalska (1984 b), cannot be used, however, for estimating the value of $N P_{t}$ at a low population density. However, this variable can be better described by a power function of the form (Bujalska, $1984 \mathrm{~b}$ ):

$$
\begin{gathered}
N P_{t}=0.719 \quad N t^{0.835} \\
r=+0.934, \quad \mathrm{n}=18, \quad p<0.001
\end{gathered}
$$

where $N P_{t}$ and $N_{t}$ as in equation (4). Equation (5) can be used when $N_{t} \leqslant 84.7$, this being the intersection point of the curves described by equation (4) and (5).

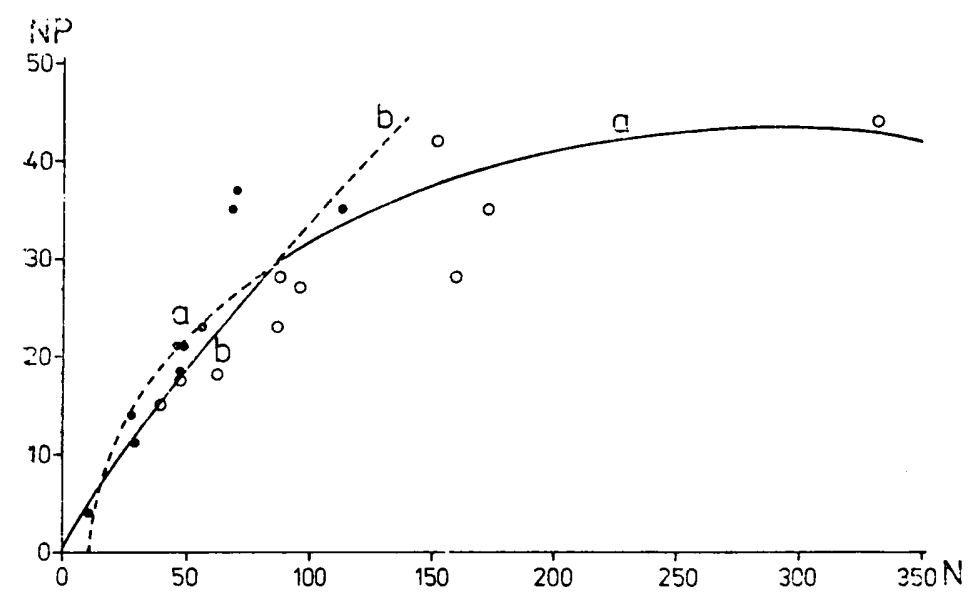

Fig. 4. The number of pregnant females (NP) plotted against the population numbers (N). Solid line denotes lsections of the curves considered to fit the empirical data. Closed circles denote empirical data from April and open ones indicate those from June. a- the curve calculated from equation (4), b - the curve calculated from equation (5).

Furthermore, no relationship was found between the number of pregnant females and population density in July and September. It may thus be suggested that changes in the number of pregnant females in the second half of the breeding season are randomly determined, like those of mature females. An attempt was made to find a relationship 
between the number of pregnant females in July and September and the number of mature females. A linear regression was found of the form:

$$
\begin{gathered}
N P_{t}=0.471+0.428 \quad N M t \\
r=+0.484, \quad \mathrm{n}=20, \quad p<0.05
\end{gathered}
$$

where $N P_{t}$ as in equation (4) and $N M_{t}$ as in equation (2).

Thus, it is not easy to describe changes in the number of pregnant females with respect to their functional relation to population dynamics. The limitation of the number of mature females in the population determines the maximum number of breeding females. The mechanism underlying the limitation of mature females is simple, and it seems to be well recognized. This allows reasonable predictions of mature females numbers over different ranges of population density. But a similar procedure applied to pregnant females is not straightforward. In April, at a low population density, the proportion of pregnant females approximates to $100 \%$ of the mature females (Bujalska, 1970). Later, however, the rate of becoming pregnant is subject to many unspecified modifications. But how does it happen that the number of young born over the breeding season is almost fixed, ranging from about 1010 to 1080 individuals (Bujalska, 1970, 1973, Petrusewicz et al., 1971), despite the fact that the number of pregnant females is a function of population density in the first half of the breeding season and varies in a rather unpredictable way in the second half of the breeding season? The limitation of the number of births (which implies a limitation of the number of pregnancies over the breeding season if $L_{t}$ and $\tau_{p}$ vary little and $T_{t}$ is fixed see equation (1)) combined with the limitation of the number of mature females and our lack of the understanding regarding the underlying ecological mechanisms inclines the author to suggest that some physiological processes (e.g. breeding "fatigue") may be involved here.

\subsection{Survival and its Determinants}

Reproductive stability, expressed for example by the fixed number of individuals born each year implies that survival and its changes alone account for differences in the population density (Bujalska, 1970, 1975 a). An analysis of the survival of different age classes has shown that the population peak in July was preceded by a higher number of individuals of nontrappable age coming from the spring generation (Bujalska, $1975 \mathrm{a}$ ). Contrariwise, in the years of low densities with no peak, nontrappable individuals of the spring generation had low survival rate. Similarly, the survival of the autumn generation at nontrappable age varied widely. 
For these two generations jointly, the proportion of individuals surviving until their first capture fluctuated from 31 to $52 \%$. The difference between these two extremes was thus $21 \%$. The survival of the trappable population (from the first capture till the end of October) showed much smaller fluctuations, ranging from 13 to $23 \%$. Thus, for the latter group of animals the difference between the extreme values was $10 \%$ (Bujalska, 1975 a).

Because of the above observed differences, the groups of trappable and nontrappable individuals were considered separately in further analysis.

It was possible to recognize some causes of the variable survival of the youngest individuals. It has been found that their survival was positively correlated with the survival of their mothers (that is, females found pregnant on the preceding census):

$$
\begin{gathered}
y=27.304+0.834 x \\
r=+0.623, \quad p<0.001, \quad \mathrm{n}=48
\end{gathered}
$$

(Bujalska, $1975 \mathrm{a}, 1984 \mathrm{~b}$ ). It may be concluded that this relationship takes place first of all in the nesting period, when the young totally depend on maternal care for their survival (Bujalska, 1975 a). But this crucial process for population dynamics still exhibits a large, unexplained variation, as indicated by relatively low correlation coefficients of the calculated regressions (Bujalska, $1975 \mathrm{a}, 1984 \mathrm{~b}$ ).

Here it is worth noting that the survival of females depends on their breeding condition (Bujalska, 1975 a). The survival of females at nontrappable age (from their birth to first capture, i.e., over a period of the first 44 days of life) was $37.1 \%$. Then the survival of mature females and immature females at the same age was 58.6 and $72.3 \%$, respectively. Thus, reproduction "shortened" the life of females. After the breeding season in winter, the survival of the two categories of females was similar and much higher than during the breeding season $(83.2$ and $85.0 \%$, respectively). In the following breeding season it was reduced to $54.1 \%$, entirely similar to the survival of mature females during their first breeding season. These results relate survival to reproduction. This relationship may be due to higher maintenance costs for mature females, including also pregnant and lactating females, which have a much higher metabolic rate than other females (Kaczmarski, 1966). But attempts to find a relationship between the survival of adult females and their spacing behaviour failed, though one might expect that this behaviour (for example, the size of individual home ranges) should reflect changes in the quantity or quality of food, as indicated by the results of a feeding experiment (Bujalska, 1975 b; Andrzejewski \& Mazurkiewicz, 1976). 
Using earlier experience (Bujalska, $1984 \mathrm{~b}$ ), the survival of nontrappable individuals in the first half of the breeding season was estimated as a function of the natural logarithm of the population density and proportion of the rearing females that die:

$$
\begin{gathered}
S U_{t, t+1}=1.033-0.0742 \text { in } N t-0.00692 M P_{t, t+1} \\
R=0.666, \quad \mathrm{n}=48, \quad F=17.96, \quad p<0.001,
\end{gathered}
$$

where $S U_{t, t+1}$ is the proportion of nontrappable individuals surviving over the period from $t$ (birth date) to $t+1$ (date of the nearest census), $\ln N_{t}$ is the natural logarithm of the population number at time $t$, and $M P_{t, t+1}$ is the mortality of pregnant females in the period from $t$ to $t+1$.

In turn, the percentage mortality of rearing females in the period between the two censuses ( 6 weeks) has been calculated as a power function of their numbers (Bujalska, $1984 \mathrm{~b}$ ):

$$
\begin{gathered}
M P_{t, t+1}=0.00179 N \mathrm{~N}^{2.85} \\
r=+0.674, \quad \mathrm{n}=24, \quad p<0.001,
\end{gathered}
$$

where $M P_{t, t+1}$ as in equation (7), $N P_{t}$ as in equation (4).

An attempt was made to describe in a similar way the survival of nontrappable individual's in the second half of the breeding season. Although the relationship between the survival of nontrappable young and that of their mothers was observed over the entire breeding season, no relationship was found between these two processes and the number of pregnant females in the second part of the breeding season. For this reason the survival of nontrappable individuals was calculated as a function of the total population size, this being the only parameter found to relate their survival to population dynamics. This is a logarithmic regression describing the proportion of surviving in the period from birth to the first capture:

$$
\begin{gathered}
S U_{t, t+1}=1.053-0.133 \text { in } N t \\
r=-0.469, \quad \mathrm{n}=48, \quad p<0.001,
\end{gathered}
$$

where $S U_{t, t+1}$ and $\ln N_{t}$ as in equation (7).

Then the survival of the trappable population has been described over the entire breeding season. The regression describing the proportion surviving over a 6 -week period between two succesive censuses (Fig. 5) is:

$$
\begin{gathered}
S T_{t, t+1}=2.111-0.638 \text { in } N_{t}+0.0684\left(\ln N_{t}\right)^{2} \\
R=0.519, \quad \mathrm{n}=46, \quad \mathrm{~F}=7.92, \quad p<0.005,
\end{gathered}
$$

where $S T_{t, t+1}$ is the proportion of individuals at the trappable age surviving from time $t$ to $t+1$, and $\ln N_{t}$ as in equation (7).

The above correlation coefficients are statistically significant but not high. Thus it cannot be suggested that survival is density-dependent. 
What is more, the results presented imply that factors other than population density are more likely to differentiate the survival of the two categories of animals.

The attempts to relate the survival of all the categories of individuals to the available food resources, such as the herb layer, failed (Bujalska, $1984 \mathrm{~b})$. So, the problem of survival, exemplified by its temporal variation for the different groups of individuals, remains unsolved.

Of particular importance to the fate of the population is survival in the period when losses due to mortality can not be compensated for by recruitment. This is the period between the end of the breeding season

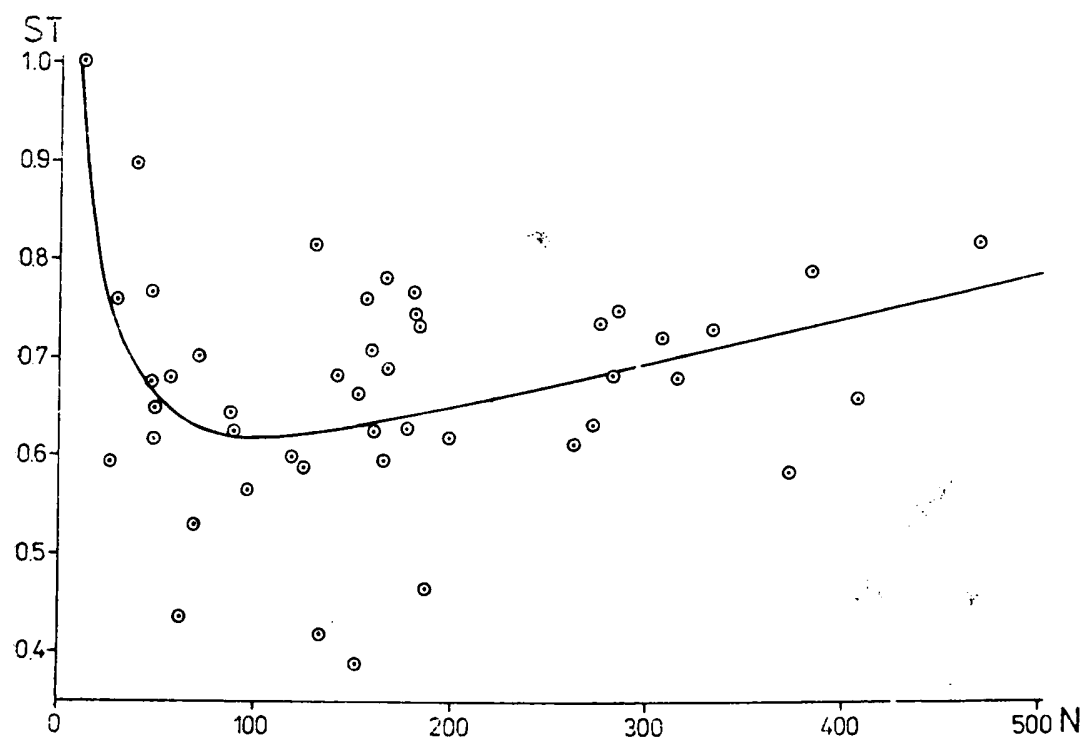

Fig. 5. Survival of trappable individuals per individual per 6 weeks (ST) plotted against population numbers $(\mathrm{N})$. Solid line shows the curve calculated from equation (10). Open circles denote empirical data.

and the onset of breeding in April of the following season. Lack of direct observations makes it impossible to assess changes in the rate of survival in particular winter months. Therefore the information was obtained by the interpolation of the numbers in autumn and the following spring.

Earlier studies on the bank vole population inhabiting Crabapple Island have shown that survival in winter is much higher than in the breeding season, and it does not depend upon age. Members of cohort $K_{1}$, which are 8 months old, on average, and cohorts $K_{2}, K_{3}$, and $K_{4}$ jointly, which were 4 monts old, on average, survived in similar proportions (89.2 and $86.7 \%$ per month, respectively; Petrusewicz et al., 
1971). As has already been noted, the participation in reproduction had no subsequent effect on winter survival.

To find the reason for the differences in winter mortality, such factors as the frequency distribution of temperatures, depth of snow cover, and amount of food available in early spring were analysed (Bujalska, $1984 \mathrm{~b}$ ). Winter mortality has been described as a complex of the influences of population density in October and the standing crop biomass of the herb layer in spring (see equation in Section 3.1.).

An analysis of the body weight of overwintered animals in April suggests that food resources in the critical period of early spring are the main determinant of the size of the breeding stock. A decrease in winter survival was related to a decrease in the body weight of individuals that had survived until spring (Bujalska, $1984 \mathrm{~b}$ ).

As has been shown, the biomass of the herb layer in April depended on temperature in the last ten-day period of March. It follows that the biomass of the herb layer can be represented by the mean minimum temperature of this period. The equation obtained describes well the relationship between the population density in April and that in the autumn of the preceding year and mean temperature in the last ten-day period of March:

$$
\begin{gathered}
N_{t}=29.24+0.231 \quad N_{t-1}+2.112 x \\
R=0.884, \quad \mathrm{n}=9, \quad \mathrm{~F}=10.70, \quad p<0.002,
\end{gathered}
$$

where $N_{t}$ is the population density in April, $N_{t-1}$ is the population density in October of the preceding year, and $x$ is the mean minimum temperature of the third ten-day period of March:

It should be remembered, however, that the effect of temperature in March on the survivorship of the population is indirect, and food resources at this time of the year are the appropriate factor. But this particular function is used in further analyses because it is easier to measure the temperature in spring than the food available.

\section{DESCRIPTION OF THE SIMULATION MODEL}

The regressions presented above characterize the main demographic processes and differences in their patterns in various periods in the life of the population. Among other things, this is indicated by the "force" of the relationship of these processes to population density in the first and second half of the breeding season. This is mainly attributable to survival but also to a lesser extent to reproduction. Although the dependence of these two processes on population density may suggest a direct effect of density on their rate or direction, it should be remembered that the causal mechanisms lie within the realm of other factors. 
In the light of understanding of this fact, the easily conceivable and readily accepted system of regulation of numbers based upon a densitydependent sequence of events should be revised, as it does not provide an adequate interpertation of the processes shaping population dynamics. But how can demographic processes be dealt with if their underlying causes are not recognized? It seems that for the immediate purpose of constructing a model we have to base such a model on the correlations obtained with population density, even though the regressions so calculated are not of the cause-and-effect type. Thus, at this stage of the analysis it will not be possible to penetrate the underlying mechanisms. We shall stay on the surface of population processes. Our purpose will be to see whether an empirical model (constructed à posteriori) will be able to simulate the population changes empirically found.

Thus, this model should: (1) reproduce the seasonal pattern of changes in numbers, (2) simulate the persistance of the population in time, with no upward or downward trend, and (3) simulate fluctuations in a way which corresponds to those observed, including for example, a decreasing value of $\mathrm{CF}$ over the breeding season and deviations from the normal distribution.

According to what has been stated above and to earlier results (Bujalska, $1984 \mathrm{~b}$ ), it is not possible to develop a model based on a single set of equations for the whole year. For this reason a model has been built for three phases to describe fluctuations in numbers: (1) in the period from April to July, i.e. in the first half of the breeding season, (2) in the period from July to October, i.e. in the second half of the breeding season, and (3) in the period October-April. Each of these three submodels thus describes three distinct periods in the dynamics of the population: the phase of dynamic changes, the inertial phase, and the phase of clear environmental influences.

1. The flow diagram of the simulation of numbers from April' to June and from June to July, that is, the model for the first half of the breeding season is shown in Fig. 6. Residual standard deviations occurring in regression equations (2) to (11), that is, for all the three submodels are given in Table 1. The submodel for the period April-July fits the empirical data particularly well: its component equations are based on well' recognized ecological situations, and as a result they have high correlation coefficients.

2. The submodel for the period July-October. It is worth noting here that in this submodel the values of $S T_{t, t+1}, \nu t, N S_{t+1}, N_{t+1}$ (for explanation of the symbols see Fig. 6) are based on identical equations for both submodels. The flow diagram and the necessary equations are shown in Figure 7. 
3. The submodel for the period October-April. The size of the breeding stock at the beginning of the season was simulated by equation (11) described in Section 3.3. This submodel closes the last stage of the entire simulation model in the period from the beginning of one breeding season

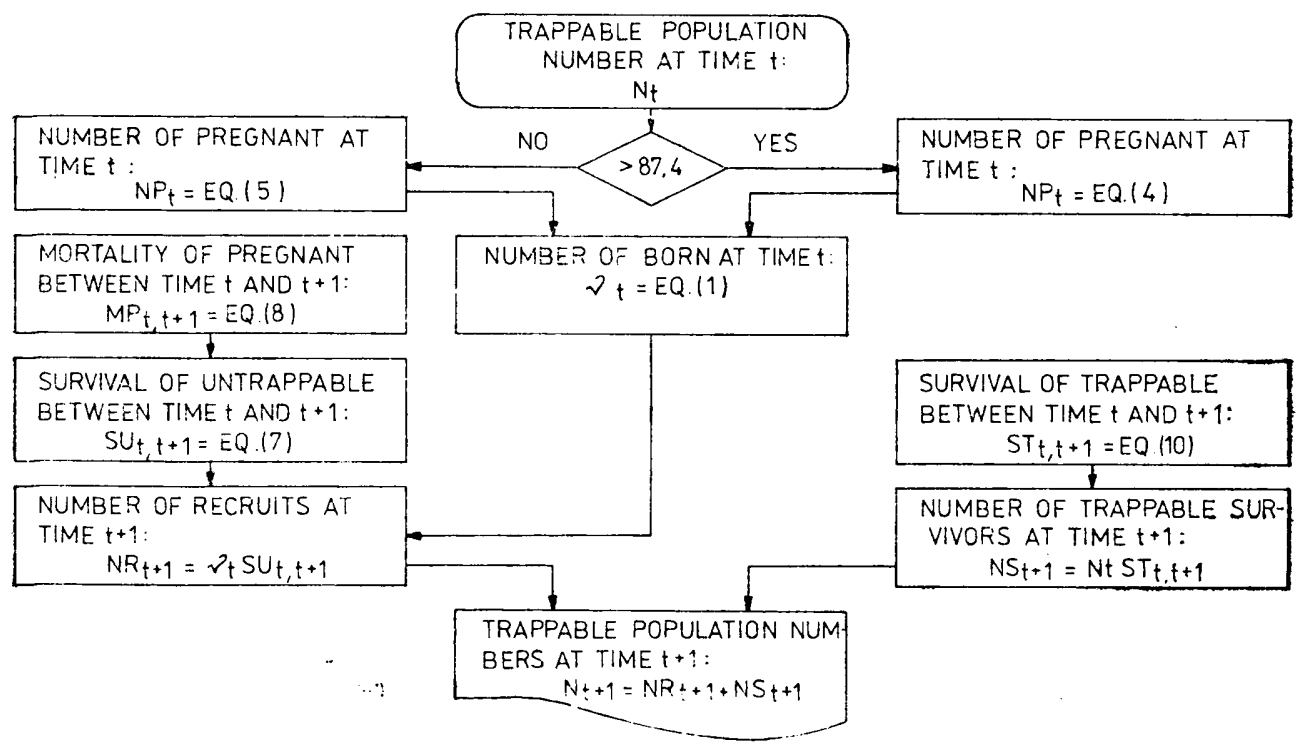

Fig. 6. Flow diagram of the submodel simulating changes in population numbers in the period from April to July.

Table 1

Residual standard deviations of the regression equations used in the simulation model of population dynamics.

\begin{tabular}{|c|c|c|}
\hline Equation & Residual standard & deviation \\
\hline (2) & 25.23 & \\
\hline (3) & 6.51 & \\
\hline (4) & 7.27 & \\
\hline (5) & 3.57 & \\
\hline (6) & 8.11 & \\
\hline (7) & 0.175 & \\
\hline (8) & 13.24 & \\
\hline (9) & 0.179 & \\
\hline (10) & 0.103 & \\
\hline (11) & 11.10 & \\
\hline
\end{tabular}

to the beginning of the next one, thus over the biological year. According to the logical scheme shown in Figure 6 and Figure 7, and using equation (11), first a deterministic and then a probabilistic simulation was run. This was a discrete simulation. On the basis of numbers in April, the 


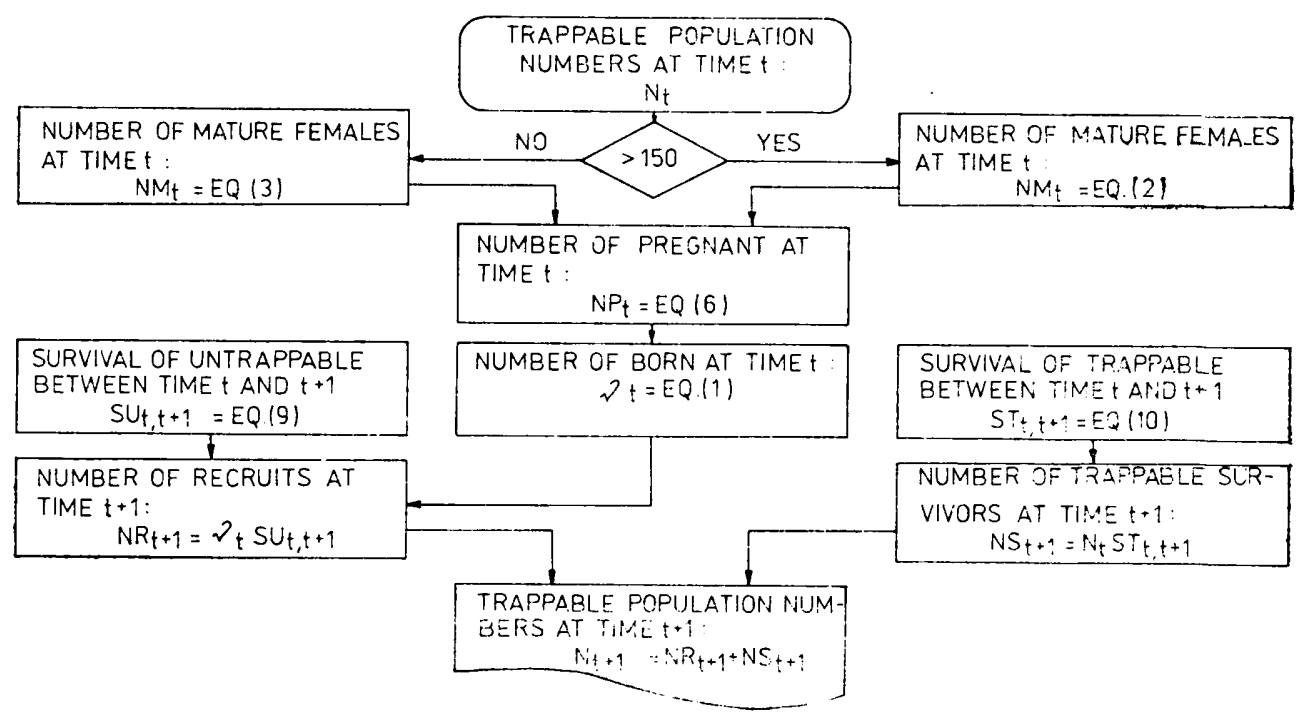

Fig. 7. Flow diagram of the submodel simulating changes in population numbers in the period from July to October.

reproduction was simulated and also the survival of nontrappable (newborn) and trappable individuals in the period from April to June. In this way the population density in June was estimated. Then this calculated density in June was used to simulate reproduction in June, as well as the survival of trappable and nontrappable individuals in the period June-July, and so on, this operation being repeated for successive 6-week periods of the breeding season, and for the 6-month period October-April of successive "study" years.

\section{RESULTS OF THE SIMULATION}

\subsection{Deterministic Approach}

The simulation of changes in population numbers allows conclusions concerning the properties of the model and the validity of the functions used. Moreover, it enables us to follow changes in the population living under ideal conditions, with no random influences, as it were in an unreal world (assuming that all standard deviations in Table 1 equal zero), in which everything is known and defined.

The simulation was run for three different initial situations. In all of them it was assumed that the temperature in the third ten-day period of March is fixed at $-10.5^{\circ} \mathrm{C}$, this being the mean value observed for the study period. Only the initial population size at the beginning of the breeding season was differentiated in the model: (1) the initial population 
density was equal to the mean value observed in April (the years in which the population was experimentally manipulated are excluded) and it comprised 67 individuals, (2) the initial population was made up of 11 individuals, thus corresponding to the lowest numbers observed at the onset of breeding, and (3) the initial population consisted of 152 individuals, which is the highest density observed (Fig. 8).
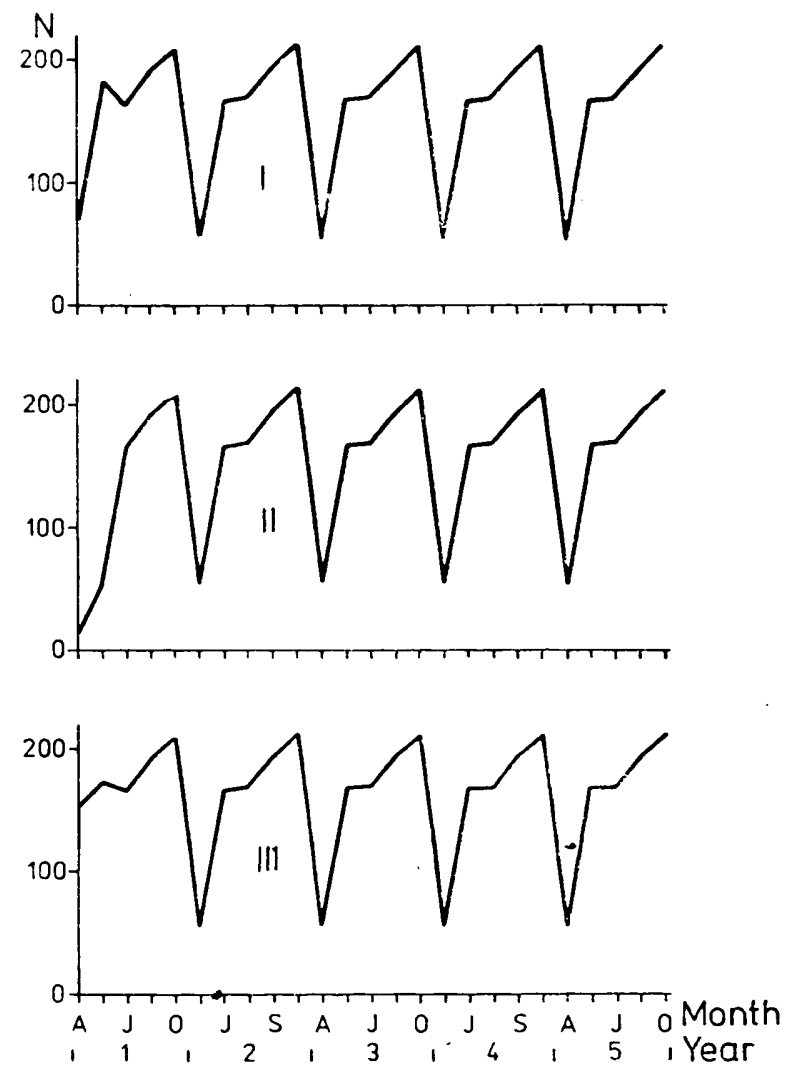

Fig. 8. "Fixed pattern" of changes in the population numbers (N), as revealed by the deterministic version of the simulation model. Initial population numbers: I 67 , II -11 , and III -152 individuals.

The results of these simulations are shown in Figure 8. After four years from the beginning of simulation, seasonal changes in population numbers in each succesive year (i.e. fifth, sixth, seventh, etc.) followed exactly the same fixed pattern of seasonal changes in numbers taken to. the 2nd place of decimals. The same pattern was established in all; three versions of the model. As the population dynamics in each year- 
was a faithful replica of that in the preceding year, the simulation was stopped after 5 "years", admitting that the population "developed" a fixed pattern of changes in numbers. This pattern shows that peak number will be most frequent in October and rarest in April.

It is worth recalling here the results of the deterministic simulation for the period April-July, according to the above classiffication, for submodel 1 (Bujalska, $1984 \mathrm{~b}$ ). In that model the population number was fixed at about 150 individuals after several or a dozen or so runs (depending on the assumptions). This may suggest that the fixed pattern of number fluctuations already develops in the first dynamic period. It has also been noted that reproduction was responsible for number stabilization.

Table 2

Comparison of seasonal changes in population number observed in successive years of the study with the fixed pattern obtained from the deterministic simulation, using the Kendall rank correlation coefficient.

\begin{tabular}{crrrrrrr}
\hline & April & June & July & Sept. & Oct. & $\begin{array}{c}\text { Probability associated with } \\
\text { Kendall } \\
\text { rank correlation }\end{array}$ \\
\hline $\begin{array}{c}\text { Fixed } \\
\text { pattern }\end{array}$ & 56 & 167 & 168 & 194 & 211 & \\
\hline 1966 & 56 & 152 & 306 & 262 & 177 & $p>0.10$ \\
1967 & 68 & 160 & 167 & 177 & 201 & $p<0.02$ \\
1968 & 70 & 332 & 383 & 373 & 230 & $p>0.10$ \\
1969 & 113 & 173 & 165 & 187 & 146 & $p>0.10$ \\
1970 & 29 & 87 & 282 & 315 & 224 & $p>0.10$ \\
1972 & 152 & 124 & 406 & 468 & 473 & $p<0.09$ \\
1975 & 134 & 181 & 284 & 271 & 181 & $p>0.10$ \\
1976 & 27 & 47 & 119 & 156 & 130 & $p<0.09$ \\
1977 & 46 & 96 & 158 & 166 & 170 & $p<0.02$ \\
1978 & 48 & 88 & 184 & 197 & 143 & $p>0.10$ \\
1979 & 47 & 62 & 130 & 141 & 112 & $p>0.10$ \\
1980 & 11 & 39 & 180 & 275 & 241 & $p<0.09$ \\
\hline
\end{tabular}

For further analysis it is necessary to see if there is a similarity; between the observed seasonal changes in numbers and the fixed pattern obtained from the simulation. The similarity is evident in the mean number of trappable individuals and in the direction of changes in numbers. In five out of 12 years of observation, seasonal trends of numbers did not deviate markedly from the fixed pattern, and in one of them (1967), the distribution of the observed population numbers fits very well to the distribution characteristic of such a fixed pattern (Table 2).

Although this result implies an unlimited persistence of the model population and fits well the observed pattern, it is not satisfactory because it is an idealization based on a tacit assumption that correlation 
coefficients equal 1 . This result only shows that both the functions describing population demography and their arrangement as shown in the flow diagrams are correct. The deterministic simulation does not perform an important task. It does not generate long-term population fluctuations, which are common in real' bank vole populations. Thus, a probabilistic simulation was undertaken.

\subsection{Probabilistic Approach}

Simulation 1. It was assumed that the mean minimum temperature of the last ten-day period of March equals the mean observed temperature of $-10.5^{\circ} \mathrm{C}$. This mean shows a random variation. Thus the "initial" temperature in each year was $X \pm \sigma \sqrt{S_{x}}$, where $\sigma$ is a normal random number, and $S_{x}$ is a standard deviation from the mean temperature $(X)$. The simulation was run for 55 years, that is for 275
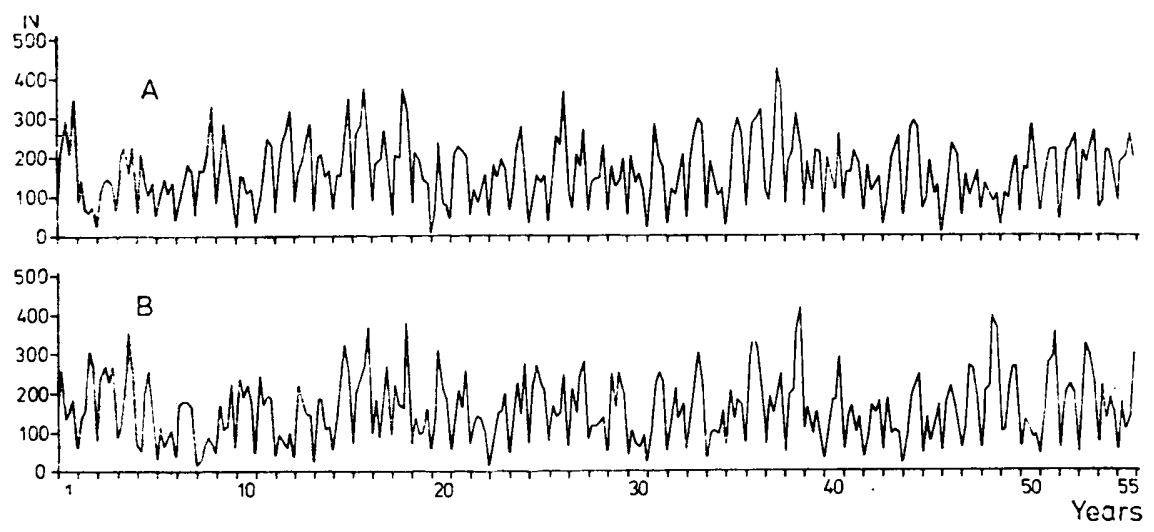

Fig. 9. Number fluctuations (N) generated by the stochastic version of the model over the first 275 censuses (55 years). A - temperature in March varies randomly,

$\mathrm{B}$ - temperature in March follows an 11-year cycle.

successive "censuses" (55 observations for each of the months considered, i.e., April, June, July, September and October). The result is shown in Figure 9.

Then the fit of the simulated numbers to the normal distribution was tested for each month. The interpretation of the result was based on the sign of the third $\left(g_{1}\right)$ and fourth $\left(g_{2}\right)$ central moment of the distribution. A negative value of $g_{1}$ was interpreted as a tendency to skewness to the left, whilst a positive one was a tendency to skewness to the right. The negative value of $g_{2}$ indicated a tendency to platykurtosis, and the positive one to leptokurtosis. Statistical significance of these tendencies was tested by the methods described by d'Agostino and Pearson (1973). 
The results of the simulation, like the empirical results, tended to be skewed to the right (Table 3). Moreover, population numbers showed leptokurtosis $\left(g_{2}>0\right)$ in April and platykurtosis $\left(g_{2}<0\right)$ in the other months.

The results of simulation were compared with empirical data. The results of all the censuses tended to be skewed to the right (Fig. 2): The emprical data are rather scarce as compared with the results of

Table 3

Deviations from the normal distribution in the results obtained from two different simulation features of population dynamics.

\begin{tabular}{|c|c|c|}
\hline Month & $\begin{array}{l}\text { Value of the } 3 \mathrm{rd} \\
\text { and } 4 \text { th central moment }\end{array}$ & $\begin{array}{c}\text { Interpretation: } \\
\text { tendency towards }\end{array}$ \\
\hline \multicolumn{3}{|c|}{ Temperature in March fluctuates randomly } \\
\hline April & $\begin{array}{ll}g_{1}= & 0.0721 \\
g_{2} & =0.1003\end{array}$ & $\begin{array}{l}\text { Skewness to the right } \\
\text { Leptokurtosis }\end{array}$ \\
\hline June & $\begin{array}{l}g_{1}=0.0379 \\
g_{2}=-0.4211\end{array}$ & $\begin{array}{l}\text { Skewness to the right } \\
\text { Platykurtosis }\end{array}$ \\
\hline July & $\begin{array}{l}g_{1}=0.3442 \\
g_{2}=-0.1229\end{array}$ & $\begin{array}{l}\text { Skewness to the right } \\
\text { Platykurtosis }\end{array}$ \\
\hline Sept. & $\begin{array}{l}g_{1}=0.4414 \\
g_{2}=-0.5785\end{array}$ & $\begin{array}{l}\text { Skewness to the right } \\
\text { Platykurtosis }\end{array}$ \\
\hline Oct. & $\begin{array}{l}g_{1}=0.5379 \\
g_{2}=-0.0890\end{array}$ & $\begin{array}{l}\text { Skewness to the right } \\
\text { Platykurtosis }\end{array}$ \\
\hline \multicolumn{3}{|c|}{ Temperature in March follows an 11-year cycle } \\
\hline April & $\begin{array}{l}g_{1}=0.1494 \\
g_{2}=0.2998\end{array}$ & $\begin{array}{l}\text { Skewness to the right } \\
\text { Leptokurtosis }\end{array}$ \\
\hline June & $\begin{array}{l}g_{1}=-0.0242 \\
g_{2}=-0.9094\end{array}$ & $\begin{array}{l}\text { Skewness to the left } \\
\text { Platykurtosis }\end{array}$ \\
\hline July & $\begin{array}{l}g_{1}=0.1584 \\
g_{2}=-0.6504\end{array}$ & $\begin{array}{l}\text { Skewness to the right } \\
\text { Platykurtosis }\end{array}$ \\
\hline Sept. & $\begin{array}{l}g_{1}=0.5136 \\
g_{2}=-0.2158\end{array}$ & $\begin{array}{l}\text { Skewness to the right } \\
\text { Platykurtosis }\end{array}$ \\
\hline Oct. & $\begin{array}{l}g_{1}=0.3390 \\
g_{2}=-0.7309\end{array}$ & $\begin{array}{l}\text { Skewness to the right } \\
\text { Platykurtosis }\end{array}$ \\
\hline
\end{tabular}

the simulation, nontheless the accordance of the characteristics of the distributions of the empirical and simulation results shows that the model resonably approximates reality.

To find out if there are similar regularities in the range of fluctuations in successive months, the CF Whittaker's (1975) index was used. A high similarity was found in the value of this index for the empirical and simulation data. It clearly tended to decline in the period ApriplOctober (Fig. 10), showing that the range of fluctuations diminished. The mechanisms accounting for this damping are in the population itself and have been analysed elsewhere (Bujalska, $1984 \mathrm{~b}$ ). Now it should be 
emphasized that the model replicated the situation observed in nature and this confirms its reliability.

This statement allows continuation of the analysis in an attempt to test whether the model generates long-term trends in population dynamics. Since the number of series in the one-sample runs test has been shown not to go beyond the critical values (Table 4), the conclusion is that the model does not generate such trends.

Simulation 2. In this simulation the effects of cyclic changes in spring temperatures on population dynamics was analysed. The starting point was a selection of temperatures of the last ten-day period of March for the years when population dynamics were observed (the spring of 1972 was excluded for the reasons given in Section 2.1.). A "cycle" of 11 years

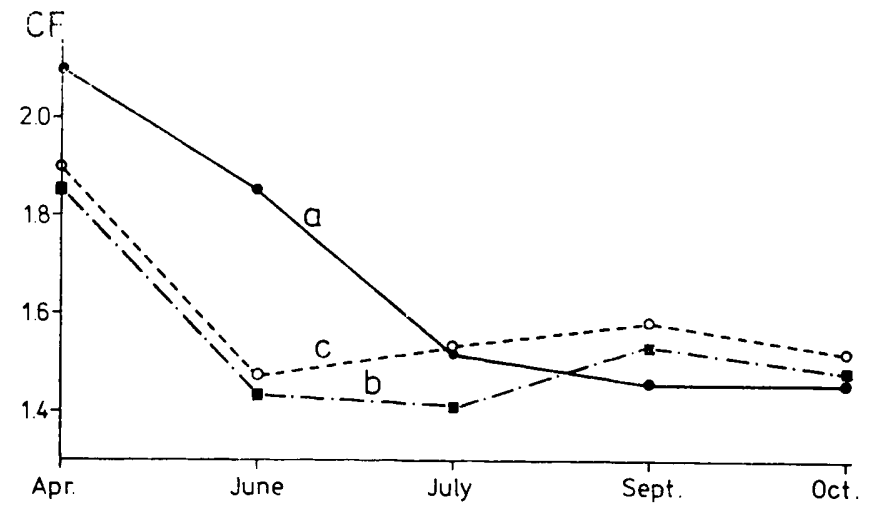

Fig. 10. Whittaker's coefficient of fluctuation (CF) calculated for empirical data and for simulation results. a - empirical data, b - results of simulation with random temperature fluctuations in March, c - results of simulation with an 11-year cycle of changes in the temperature in March.

was thus selected to compare the results of the simulation with those obtained on the assumption that temperatures in March vary randomly.

The amplitude of the fluctuations was analysed in successive months. Changes in value of $\mathrm{CF}$ show that it followed the same pattern as in simulation 1, and thus also the empirical results. That is, it was highest in April and than dropped in June, and stabilized in the remaining months (Fig. 10). Next, the distribution of the simulated population numbers was compared with the normal distribution. The results of the simulation tended to be skewed to the right (Table 3). The only exception was the results for June. This tendency correspond to that observed in the real population. As in simulation 1, there was a tendency to leptokurtosis in the distribution of numbers in April which was also 
present in the empirical material. In the other months of the year, the simulated number distribution is characterized by platykurtosis. Thus, in this case the model was also consistent with the empirical pattern. This pattern and its demographic implications will be discussed in Section 6.

The tendency to leptokurtosis in April combined with the observed value of $\mathrm{CF}$ can be interpreted as follows. In April it is most probable that population numbers will deviate little from the mean value, but the probability of large deviations from the mean is not low. The tendency to platykurtosis in the other months, combined with relatively low CF values, can be interpreted as an indication of similar probabilities of the occurrence of different population numbers within some limits. Beyond these limits this probability is very low.

Table 4

Number of runs (a run consists of a sequence of increasing or decreasing values) in the results of the simulation of population dynamics over 55 successive years.

\begin{tabular}{lccc}
\hline Month & \multicolumn{2}{c}{ Simulation feature } & $\begin{array}{c}\text { Critical range of } \\
\text { runs (for n=55, } \\
p=0.05 \text { ) in the } \\
\text { one-sample runs } \\
\text { test }\end{array}$ \\
\hline $\begin{array}{c}\text { Temperature in March } \\
\text { follows an 11-year } \\
\text { cycle }\end{array}$ & $\begin{array}{c}\text { Temperature in March } \\
\text { fluctuates randomly }\end{array}$ & \\
April & 33 & 34 & $27-45$ \\
June & 37 & 33 & \\
July & 38 & 38 & 39 \\
Sept. & 33 & 41 & \\
Oct. & 31 & & \\
\hline
\end{tabular}

An ecological interpretation of the tendencies described above may be as follows. In early spring, prior to the onset of breeding, population density is determined by environmental constraints due to one or two factors (food and temperature). Hence, probably, a large deviation from the mean value may occur. In the other months of the year population density is stabilized within specific limits.

In the process of simulating numbers in April the population went extinct in one out of 110 cases ( 55 runs for each of the two variants), and the island had to be "recolonized". Thus, it is worth emphasizing that there are consequences of random variation in the size of the breeding stock for the fate of the population. In other words, there are no processes protecting the population from the excessive decline. Thus, it is possible that under unfavourable circumstances (low population numbers in autumn, low temperatures at the beginning of the breeding season), extinction may be a common event. The only protection involved: in the population strategy seems to be the relationship between reproduc- 
tion and mortality, that has been discovered by an analysis of the results of simulation (Bujalska, $1984 \mathrm{~b}$ ).

\subsection{Do Population Cycles Exist in the Bank Vole?}

The analyses presented so far support the thesis that the results of the two simulations (with random and cyclic changes in temperature) reasonably well reproduce the population fluctuations observed on the island. An additional support for this conclusion is provided by the analysis of the frequency of seasonal peak numbers in a series of data from observations and from the two simulation variants (Table 5). The Kolmogorov-Smirnov test for independent samples shows that the hypothesis that the frequency distribution of peak numbers in particular months originates from the same total population cannot be rejected.

Table 5

Frequency distribution of seasonal peak numbers in empirical data and simulation results.

\begin{tabular}{lcccc}
\hline Month & $\begin{array}{c}\text { Empirical } \\
\text { data }\end{array}$ & $\begin{array}{c}\text { Simulation feature } \\
\text { Temperature in } \\
\text { March fluctuate } \\
\text { randomly }\end{array}$ & $\begin{array}{c}\text { Temperature in } \\
\text { March follows an } \\
11 \text {-year cycle }\end{array}$ & $\begin{array}{c}\text { In two } \\
\text { simulations } \\
\text { jointly }\end{array}$ \\
\hline April & 0 & 0 & 0 & 0 \\
June & 0 & 11 & 8 & 19 \\
July & 3 & 12 & 10 & 22 \\
Sept. & 6 & 10 & 18 & 41 \\
Oct. & 3 & 22 & 19 & 28 \\
\hline
\end{tabular}

This encourages further analyses of population properties generated by the model under different patterns of climatic (food) condition at the beginning of the breeding season. Having two model populations (each simulated for 55 years), an attempt was made to test them for cyclic changes in numbers (obviously, neglecting the seasonal cycle). For this purpose a time series made up of population numbers $\left(N_{t}\right)$ in successive time units, that is years $(t=1,2, \ldots n)$, was tested for periodicity. The data from April were considered and, separately, from July.

To normalize the data (skewness of the distribution) a logarithmic transformation of population numbers was used: $Z_{t}=\ln N_{t}$, and then the autocovariance function $\left(C_{k}\right)$ was estimated for the value of $Z_{t}$ and the value of $Z$ measured $k$ units later $(k=0,1,2, \ldots n-1)$ :

$$
\begin{array}{cc}
C_{k}=\frac{1}{\mathrm{n}} \quad \sum_{t=1}^{\mathrm{n}-\mathrm{k}} & \left(Z_{t}-\overline{\mathrm{Z}}\right)\left(Z_{t+k}-\overline{\mathrm{Z}}\right) ; \\
\overline{\mathrm{Z}}=\frac{1}{\mathrm{n}} \sum_{t=1}^{\mathrm{n}} & Z_{t}
\end{array}
$$


Since the estimates based on the autocorrelation function $\left(r_{k}=C_{k}: C_{0}\right)$ can be deceptive (Box \& Jenkins, 1970), the power spectrum of the time series was analysed. Such an analysis allows a critical evaluation of periodicity in population fluctuations (Jenkins \& Watts, 1968). A smoothed estimator of the power spectrum was used (Box \& Jenkins, 1970):

$$
C(f)=2\left[C_{o}+2 \sum_{k=1}^{n-1} \quad \lambda_{k} c_{k} \cos (2 \pi f k)\right]
$$

where $f$ is frequency of peak numbers and $\lambda_{k}$ denotes spectral windows used for smoothing the spectrum. The spectral windows $\lambda_{k}$ have been accepted after Finerty (1980):

$$
\lambda_{k}=\frac{1}{2}\left(1+\cos \frac{\pi k}{M}\right)
$$

Three different values of the window width recomended by Finerty (1980) were used: $M=\mathrm{n}^{\prime} / 10, M=1 / 2[\mathrm{n} / 10+\mathrm{n} / 4]$, and $M=\mathrm{n} / 4$. The evidence for the periodicity in population numbers of the period $1 / f$ is provided
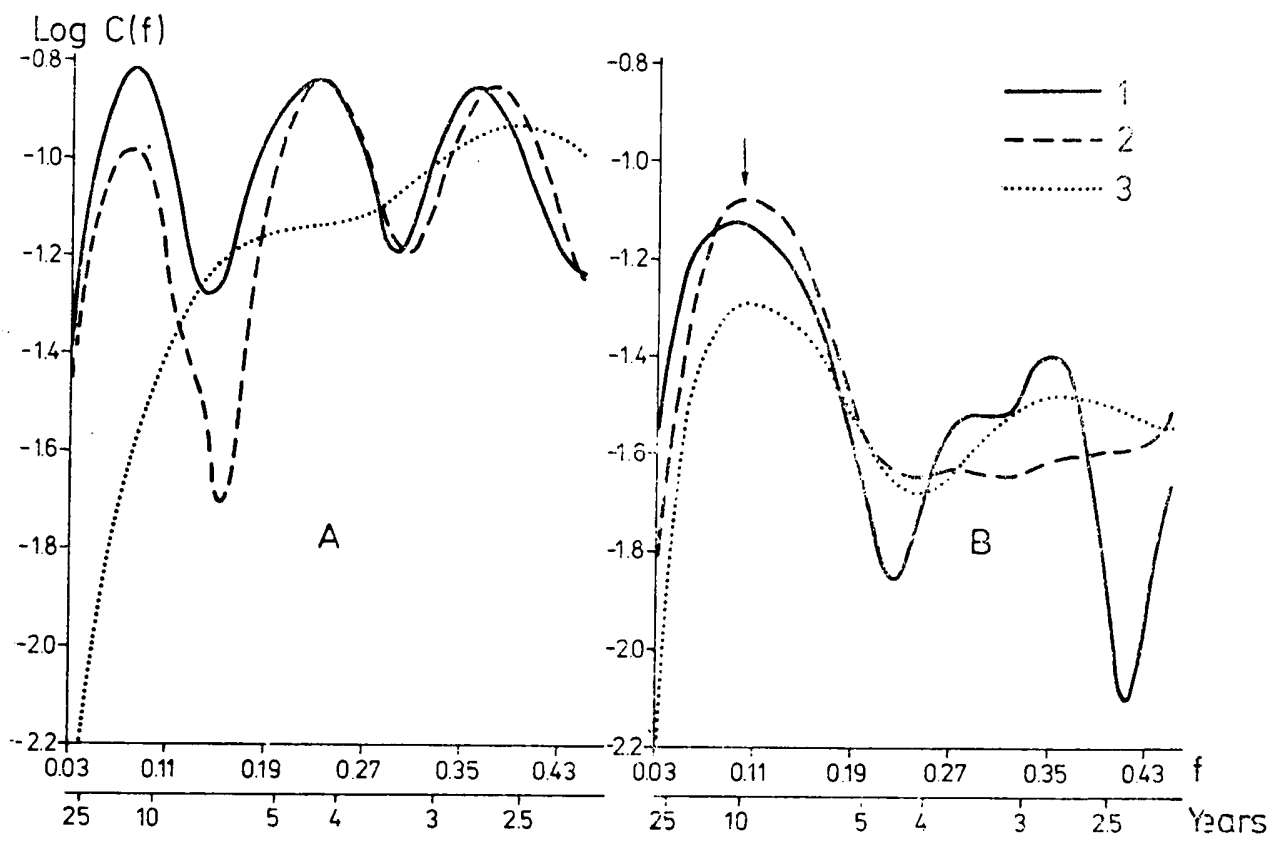

Fig. 11. Power spectrum of the autocovariance function calculated for the re:ults of simulation in April. 1, 2, and 3 - bandwidth 14, 9, and 6 years, respectirely. A - simulation results at randomly fluctuating temperatures in March, B - re:ults of simulation with temperatures in March following an 11-year cycle. Log $C($ ) logarithm of the power spectrum estimator, $f$ - frequency, $Y$ - period of the cycle in years. Arrow denotes occurrence of a cycle. 
by the coincidence of peaks for spectral estimators $(C(f))$ with the three above window widths.

The application of spectral estimators for analysing population cycles in the probabilistic simulation has revealed that when temperatures at the end of March vary randomly, then the population number in April vary also randomly (Fig. 11) and in July is cyclic with a period of about 2.6 years $(f \approx 0.385$ ) (Fig. 12$)$. If the temperature at the end of March shows an 11-year periodicity, then population number in April also varies in an 11-year cycle (Fig. 11), and a "trace" of an 11-year cycle is also preserved in July (Fig. 12).

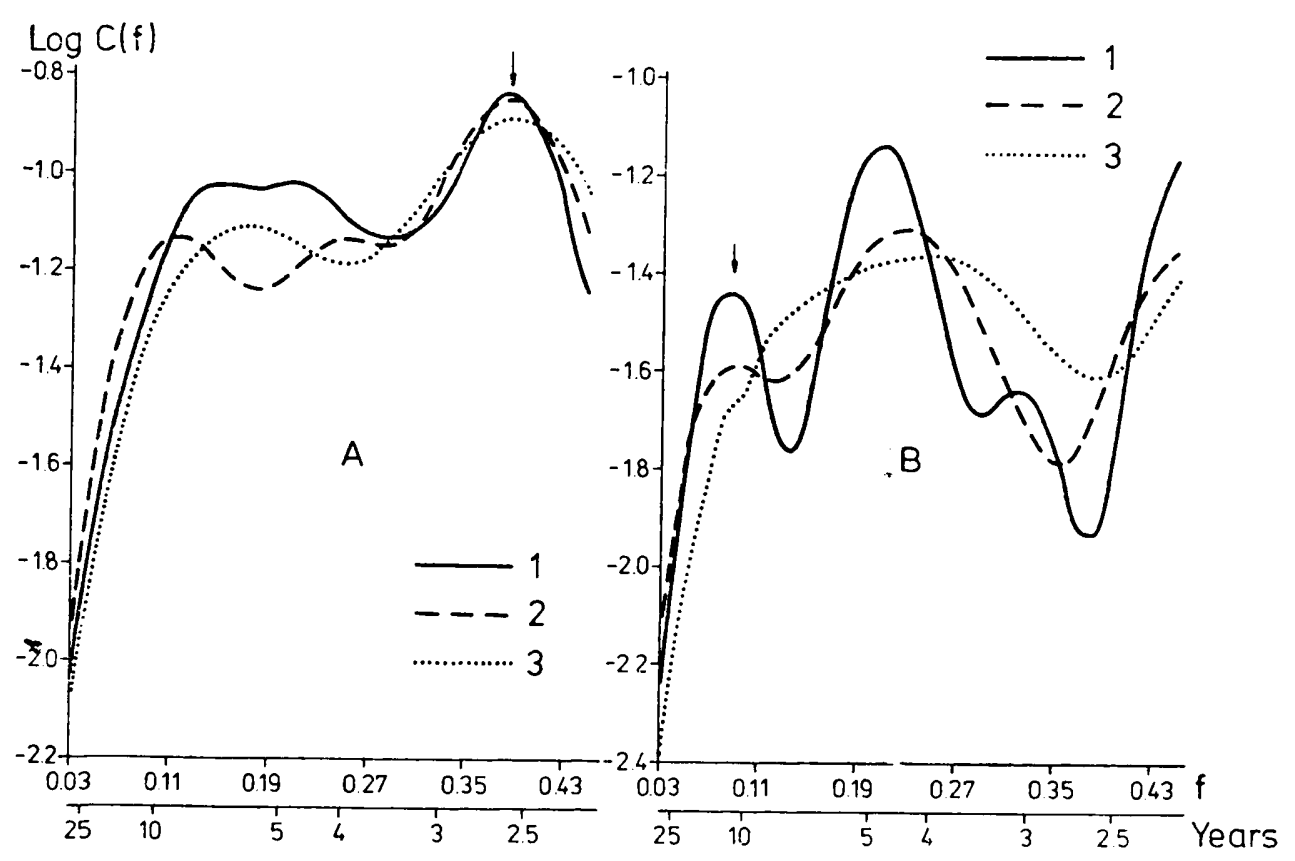

Fig. 12. Power spectrum of the autocovariance function calculated for the results of simulation in July. (Symbols as in Fig. 11).

The above results raise some questions concerning population properties not revealed earlier by analytical methods. First of all, why can the 11-year cycle in April also be traced in July? This peak is very distant from the initial state in April and only indirectly related to it (Bujal'ska, $1984 \mathrm{~b}$ ). Why do the two variants of the model transmit oscillations differentially? In other words, why do random changes in numbers in April yield a clear-cut 2.6 year cycle, and the 11-year cycle in April preserves a trace of this rhytm in July? Is this a property of 
the model or a, so far, not recognized property of demographic processes?

Let us assume that the empirical model described here generates processes occurring in the real world. All the patterns revealed by the model could have been discovered in empirical studies carried out over a sufficiently long time.

The implications of this analysis mostly concern population cycles and their relation to climatic and food conditions.. These relationships have already been discussed by many authors over many years. Especially, the effect of winter or early-spring conditions on the initial population size has been frequently emphasized (Popov, 1960; Koshkina, 1965; Fuller, 1969; Ivanter, 1975; Bujal'ska, 1984 b). The model shows that the random variance of spring conditions can generate a 2.6 year population cycle. Thus the period of the cycle does not deviate from that observed in voles: in the review by Krebs \& Myers (1974) there is information that it lasts $3-4$ years. $C$. glareolus is not an exception here. There is also information on two-year cycle (Hansson, 1979; Gliwicz, 1980) and a longer, 3-4-year cycle (Kaikusalo, 1972; Viro, 1974; Larsson \& Hansson, 1977; Hansson et al., 1978; Zejda, 1981).

We cannot reject the view that some climatic characteristics show cyclic variations, thus they must be determined by a superior factor (e.g. solar or moonlight activity as suggested by Sivonen and Koskimies, 1955). If this is really the case then we may expect a cycle in population dynamics corresponding to this rhytm of climatic conditions (and the associated food conditions). A similar pattern was obtained in the second version of the empirical model, based on cyclic changes in spring temperatures. Cycles of a similar period were observed in C. glareolus inhabiting Siberia (Ivanter, 1981). As the author suggests that these cycles were caused by the changes in food conditions and spring temperatures (in May), which determine the survival of the breeding stock, it can be expected that climatic conditions fluctuated regularly there.

It is worth remembering, however, that not all bank vole populations are cyclical. Some populations are stable, as for example in southern Sweden (Bergstedt, 1965; Hansson, 1978, 1979), and according to Ivanter (1981) even over the entire southern range of this species in contrast to the northern part of the range where there are violent fluctuations observed. Hence, there is only a single step to the pronouncement that synchronous changes in bank vole populations should not al'ways be expected, and there are many examples of this (Viro, 1974; Koshkina \& Korotkov, 1975; Ivanter, 1981). Some consequences of this situation will be discussed below. 


\section{DISCUSSION}

"Only time reveals where the true is"

Leonardo da Vinci (Cod. M., 58 verso)

Changes in numbers of small rodents have been investigated for many years. The attention of ecologists has been focused upon the patterns of increases and decreases in numbers in both seasonal and long-term cycles.

Krebs \& Myers (1974) in their review of recent advances in this field also attempted to identify the reasons for the inadequate recognition of periodic changes in numbers. But since then much has changed. The number of publications discussing different aspects of number fluctuations has increased (Lidicker, 1978; Wiger, 1982; Bujalska 1984 b; Adler \& Tamarin, 1984; Taitt \& Krebs, in print). Finerty's (1980) book provides not only a critical review of the current state of knowledge but also some new research possibilities by putting forward efficient techniques of analysis allowing an objective evaluation of the cycle period. Also we, ecologists, are less inept than heretofore. And it is no longer easy to concur with the suggestion of Krebs \& Myers (1974) that small rodents are not good subject for ecological studies: simply we have not used appropriate tools, and have been too impatient in our work, outdoing each other in inventing underlying reasons of number fluctuations (often taking effects for causes).

The search for the causes of number fluctuations has lead to an' omnipotent view that they can be observed as a result of the processes regulating population density. This interpretation has become an axiom with time. It blended so much the tradition of ecological thinking that all the processes important to changes in numbers were finally considered as having regulatory function. This approach was probably enhanced by achievements in the field of cybernetics, that showed new possibilities of interpretation, and also by the results of long-term field studies, showing that mean population densities were maintained at a stable level (interpreted as the optimum density) about which numbers oscillated for tens of years.

The modern views on population fluctuations stem from two theoretical concepts. One of them emphasizes the role of environmental factors, most of all' food and climatic conditions, in determing changes in population dynamics. A depletion of available food resources (total or to a specified degree) accounts for an inhibition of reproduction (e.g. Pitelka, 1958) and/or increase in mortality (Lack, 1954), this being followed, in turn, by population decline (Thompson, 1955; Pitelka, 1958). After the restoration of food resources the opposite process is observed and the 
population "fills" the habitat to its carrying capacity. Habitats characterized by a higher capacity "harbour" a higher number of individuals than those which are poor (Zejda, 1976, 1981; Holišova \& Obrtel, 1979; Hansson, 1978). Thus, population numbers closely tracks environmental resources.

This concept gave rise to other, increasingly refined views suggesting that not only the amount but also the quality of food may influence population density (Pitelka \& Schultz, 1964; Kalela, 1962; Schultz, 1969). As a consequence of this idea, the quantity and/or quality of food is frequently related to climatic conditions, leading back to the primordial cause, that is, the activity of the Sun.

The other concept, which gave rise to the greatest number of current ideas, goes back to the theory of intra-population regulation (Strecker \& Emlen, 1953; Clarke, 1955; Southwick, 1955; Christian, 1956; 1971, Christian et al., 1965). According to this view, the population is a selfregulating system, able to modify the direction of its change after exceding some threshold densities. At low densities, population reproduces at a high rate, mortality is lower, and the population density freely increases. With increasing density, however, the rate of further increase declines. Interactions among individual animals become more intense, and even heavy fights are possible (Koshkina, 1965; Christian, 1971), also cannibalism, etc. and then the population density drops. This is the result of a direct elimination of individuals or through a complex stress process reducing reproduction (Crew \& Mirskaia, 1931), with all its nuances (reduction in the rate of sexual maturation, disturbance of the oestrus cycle, lack of fertilization because of ineffective copulation, resorption of embryos, and so on (Southwick, 1955; Crowcroft \& Rowe, 1957; Hoffman, 1958; Christian \& Davis, 1966), and increase in mortality (Christian, 1950; Frank, 1953).

Although the concept of density-dependent number regulation is sufficient for some purposes such as an explanation of the mechanisms of increases and decreases in number (Wiger, 1982), it seems to be insufficient and mechanistic in view of the commonly known facts of the biology and ecology of the species. The orthodox concept of densitydependence, interpreted according to the views of its authors, does not allow deviations from its strict and univocal definition (Murray, 1982). It is based on the assumption that all individuals are equal. In the play for survival they are nothing but pawns. They are pawns because no other chessmen exist.

At the same time, there exists a rich documentation showing that the population is a structured system, and the problem of who will be eliminated from this system is not unrelated to its future fate (Wynne- 
Edwards, 1962). In laboratory-reared populations, where extremely high densities cannot be reduced by emigration, socially inferior individuals are excluded from reproduction or die under unfavorable conditions (in overcrowded populations in which no "horizontal" spatial structure exist, "vertical" structures are developed, that is, social hierarchy (Anderson, 1961)). This has been shown in many papers (Retzlaff, 1938; Christian, $1955 \mathrm{~b}$, and others). These facts go beyond the framework of simple density-dependent responses.

This gave rise to the need for other interpretation of regulatory processes, which do not contradict the known facts. Thus, Petrusewicz (1966) has proposed a model' of structure-dependent regulation. According to this concept, each population has structures of different types, performing specific functions in the dynamics of the population. A recognition of these functions allows the understanding of population organization. This line of reasoning, further developed by Petrusewicz's followers, is now supported by many observations. The role of different structures in the bank vole has been described, as has the age structure (Andrzejewski, Petrusewicz \& Waszkiewicz-Gliwicz, 1967), social structure (Rajska-Jurgiel, 1976), and spatial structure (Bujalska, 1970, Mazurkiewicz, 1971). It has also been pointed out that specific structures, for example, the spatial structure of the distribution of mature females in the breeding season which determines reproduction, cease to exist upon termination of the respective process (Bujalska, 1973). This underlines the dynamical arrangement of structures and thus also population organization.

From these diverse structures, we should select those which are of fundamental importance, that is the structures directly related to demographic parameters. Among them first of all there is the division of population members into those potentially capable of reproducing (sexually mature) and those forming a "reserve", temporarily not capable of reproducing (immature) (Bujalska, 1970, 1973, 1984 b, 1985). The present paper continues this line of reasoning and its intention was to illustrate the consequences of this aspect of organization for the fate of the population. This idea will be gradually developed and falsified here.

The genus of Clethrionomys is usually considered as showing little changes in numbers. Records of its mass appearance are rare. Thus, it is c.assified as a $K$-strategist, in which the limitation of reproduction is often emphasized (Kalela, 1957; Koshkina, 1965; Jewell, 1966; Bujalska, 1970; Koshkina \& Korotkov, 1975; Saitoh, 1981). A more detailed review of this issue is given by Bujalska (1985). Reproduction is limited due to territorial tendencies in mature females (Tanaki, 1953; Koshkina, 1965; Bujalska, 1970, 1973; Koshkina \& Korotkov, 1975; Saitoh, 1981). From 
this simple and well recognized mechanism (knowing that individual territories are incompressible and that some part of the territory, called a breeding territory, is al'ways free (Viitala, 1977; Wiger, 1982)), a pattern of reproduction can be deduced. This pattern involves competition among mature females for space, masked by our fashion of reasoning in terms of density-dependence, and it seems that in the later phase all females can compete for maintaining or reaching the status of a mature female (Bujalska, 1985).

The number of mature females in the population is a function of the size of the individual territories and their degree of overlap. The size of individual territories, in turn, is determined by the carrying capacity of the habitat in terms of food (Golikova, 1958; Nikitina \& Merkova, 1963; Bujalska, 1975 b; Andrzejewski \& Mazurkiewicz, 1976). Hence, food resources determine the maximum number of potentially reproducing females. This extremely simple way of fitting the reproduction to the actual food supply may have been a key when environmental capacity is not recognized (this being frequently the case) to solving the mystery of the balance between population processes and environmental capacity. Unfortunately an excessive faith in the commonplaceness of densitydependent processes precluded, I think, the application of this key.

The inhibition of the maturation rate in females, which limits the number of mature females, seems to be an important step towards the limitation of reproduction. A superficial interpretation of this fact caused mortality to be considered as process determining changes in numbers (Bujalska, 1970, 1975 a).

The simulation model, in which reproduction follows the known empirical functions and mortality is fixed, has revealed the fact, difficult to predict by deduction, that reproduction alone is the process responsible for reducing the range of changes in population numbers, this occurring in the first half of the breeding season (Bujalska, $1984 \mathrm{~b}$ ).

Also an attempt was made to relate mortality to population dynamics, assuming that this process would also reveal a "corrective" role in damping fluctuations. According to the earlier results (Bujalska, 1975 a), it was mostly the survival at the nesting age which was considered. Although a relationship was found between the survival of the youngest individuals and the survival of females, it was not possible to go out of the circle of mechanisms and to find an explanation upon which the female mortality depends. None of the factors traditionally known to modify survival (e.g. food supply, population density) was correlated with the survival of mature females. The above results both experimental and those obtained from the model suggest that the survival of the population analysed depend mainly on "random" events (inluding preda- 
tion, infection etc.). And although field observations show that survival is related to reproduction (lower survival of mature than immature females and an increased survival after breeding (Bujalska, $1975 \mathrm{a}$ ), it does not seem to be the driving force of the population dynamics. This is even more surprising in view of paramount importance of mortality pointed out in many studies on populations with no migrations (e.g. Krebs, Keller \& Tamarin, 1969).

It may be worth discussing some special problems concerning the fluctuations in numbers. First of all, the nature of the influence of environmental' factors on the rate of processes enhancing or limiting pepulation numbers. At this point we should be interested in the next stage in the network of causal relationships that is, interrelationships between the two main processes: reproduction and mortality. They do not seem to follow two independent pathways but are interrelated, at least, within certain limits of population numbers. As the model developed earlier (Bujalska, $1984 \mathrm{~b}$ ) may imply, at low population density an increase in reproduction is coupled with a decrease in the mortality of newborn individuals. This mechanism seems to protect the population from extinction; small populations may go extinct by purely random occurrences, like a sudden deterioration of food condition or a local catastrophe. Later, at higher densities, this relationship between reproduction and mortality seems to disappear.

At low population densities at the beginning of the breeding season, that is, when numbers start growing, both reproduction and mortality (thus also population numbers) are strongly influenced by the food conditions, although this relationship tends to disappear with time. In this period, the successive population sizes are not so closely related to the preceding numbers as in the half of the breeding season, that is when the population reaches higher densities. It can be suggested therefore that the period when population builds up its numbers is governed by other rules and characterized by other demographic mechanisms than the period when population density is high.

Let us consider what has changed in the habitat and in the population itself concurrently. Most of all, the dynamic growth of plant cover ensured an abundant food supply in the period of high numbers. In the almost climax forest with new herbaceous plant species gradually appearing from spring to autumn and reaching full growth at different times of season, the shortage of any nutrient in the food, e.g. nitrogen, which could reduce the survival of the young (White, 1978), is difficult to imagine.

A: the same time, the high population density meant the maximum breecing potential had been achieved. The number of females in breeding 
condition then stabilized, and also a pool of females able to replace them (the "reserve") was present, as the current-year females were capable of breeding immediately when a mature female died (Bujal'ska, 1973). However, the rate of reproduction and mortality (determining, as it would seem the expected balance between population density and carrying capacity) did not depend on the population density. How did it happen that these crucial processes escaped from being controlled by the whole population (i.e., by the parameter "population density"), and population numbers drifted through the sea of chance? In the light of the sequence of events described above there may be only one answer: the total number of individuals is not the subject of population "endeavour".

Remaining in the world of known facts, let us try to arrange them in a different way from that suggested by the theory of density-dependence. It will appear then that: (1) only that part of the population structure is regulated which secures its persistence in time and space, and this is the breeding potential, expressed by the number females able to reproduce, and probably males as well, their number being also limited as found by Kalela $(1957,1971)$ and Bujalska (1984 a). This regulation is of a stabilizing type (consequently it tends to stabilize the population size), showing resistance to disturbances. The function of this stable system is possibly due to the reserve of immature individuals. By the time that this reserve is produced, we can observe in the population some mechanisms accelerating its production (a relationship between reproduction and mortality); (2) the size of reserve can fluctuate widely. It is likely to be subject to diverse and not always recognized factors; and (3) total numbers (breeding individuals and the reserve) shows a relatively high range of fluctuation because at higher densities the survival of the trappable individuals increases with density (Fig. 5) which can destabilize the population size. Thus, to explain fluctuations in numbers there is no need to resort to the theory of density-dependent regulation which only diverts attention from actual processes.

At this point it is time for a reflection on the tortuous pathways in the history of research. The fundamental information given by Tanaka (1953) on territorial tendencies in mature females could have change the views of many workers and shorten the way toward understanding fluctuations in numbers. From this information it is possible to deduce that the limitation of reproduction and the differential spatial behaviour of females of the two categories (mature and immature) must lead to the negation of density-depend regulation.

It is also worth noticing that Fuller (1969), who discussed the role of adverse weather in population decline, pointed out that demographic 
processes should not be interpreted in terms of density-dependence when the knowledge of habitat quality provides sufficient explanation.

The empirical model described in this paper shows that it is possible to stray from the canons of the theory of density-dependent regulation. Population dynamics generated by this model does not deviate from that observed in nature; the population can persist with no upward or downward trends and shows fluctuations in numbers.

These findings produce some implications for the population theory. For example, the extent of the dispute on single- or multifactorial causes of population fluctuations shrinks. It is obvious that random changes in population numbers (reserve) open ways to causes of many types. Similarly, the problem of factors modifying the survival of the reserve will be of secondary importance unless this survival becomes so low that the whole breeding potential is threatened. This view is consistent with the earlier concept of Hansson (1978) on local causes modifying population numbers.

The reality of this concept and al'so of the view that changes in the size of the reserve are at random (at the present state of knowledge) is supported by the results of many studies cited in Section 5.3. showing large variability in the amplitude of fluctuations and their frequency under different ecological conditions.

The model proposed above implies that the views on the importance of migration to population dynamics should be revised. Except for its genetic aspect (information), it will be of secondary importance unless, for instance, the emigration does not exceed the level at which the population breeding potential' can be threatened. At the same time, an increased immigration could increase the density of females above a certain critical level, and then the mechanisms reducing the abundance of the reserve could be released (through the limitation of reproduction until its total inhibition) (Bujalska, 1985).

Independent of the views on the role of population density in demography, its causes and effects, density is an actually existing category. Even if, according to what was stated above, it can be considered as "by-product" of the processes regulating the breeding potential of the population. The total' number of individuals in a population realizing a specific niche in the trophic chain, accounts for the balance of many processes in the ecosystem. They include consumption, interactions with populations of other species in the community (competition for food and space), as well as transfer of matter to other trophic levels. Also man often wants to know how many animals he can harvest, or how many animals can threaten his crops, and also what the chance of survival is for a small populations of a species threatened with extinction, 
this latter becoming an especially urgent problem in recent times. Hence, the considerations of population numbers are not academic.

The earlier results (Bujalska, $1984 \mathrm{~b}$ ), also presented and discussed here, show that the island bank vole population fluctuates in a rhytm imposed by environmental changes. The cycle of numbers is induced by randomly changing climatic and food conditions (2.6-year cycle) or by any, e.g. 11-year, cyclic changes in these conditions (a weaker, 11-year cycle). It would be extremely interesting to explain how it is possible to retain a trace of the 11-year cycle, or to develop a 2.6-year cycle in spite of the work of the demographic machinery regulating the rate of population growth (towards suppressing fluctuation). The present results do not provide an answer to the question why two models based on the same empirical functions yield cycles of different periods.

Although the models presented here are rooted in the bank vole population inhabiting the Crabapple Island, they can be discussed in a broader context. First of all, it is worth considering if the model described here can be applied only to island situations. Although Gliwicz (1980) has argued that island populations have different strategies as compared with those of "open" populations, this does not seem to have a bearing on all population processes. For example, the limitation of reproduction - the most important process indicating the "choice" of the population life-strategy - is equally frequently described for both open and confined bank vole populations, including island populations (Kalela, 1957; Jewell, 1966; Bujalska, 1970, 1973; Koshkina \& Korotkov, 1975; Saitoh, 1981). Thus, there is no reason to argue that stabilization of reproduction is limited exclusively to island populations.

It may be suggested that the reasoning underlying the model presened here will hold for rodent populations the strategy of which is based on the limitation (regulation) of their breeding potential (Bujalska, 1981). It may apply not only to the populations of the genus Clethrionomys but also to the majority of so-called $K$-strategists.

Acknowledgements: This study would not have been possible without the assistance of many people. Krzysztof Banach, M. Sc., and Hanna Plewka helped in organizing field expeditions, collecting material and processing data. Wanda Sianożęcka took care of necessary equipment. Dr. Robert Kowalski, Professor Zdzisław Pucek, Professor Przemysław Trojan and Dr. Janusz Uchmański made comments on the first draft, and Barbara Diehl, M. Sc. noticed some inconsistencies when translating this paper into English.

I am particularly indebted to my husband, Assistent Professor Leszek Grüm who showed much patience and indulgence over many years, spent much time in discussion, and helped me me in the mathematical processing of the data. I used his HP $34 \mathrm{C}$ programmes for all calculation and simulations.

I am also grateful to those circumstances which created this opportunity for me to carry out this study. 


\section{REFERENCES}

1. Adamczewska K. A., 1961: Intensity of reproduction of the Apodemus flavicollis (Melchior, 1830) during the period 1954- 1959. Acta theriol., 5: 1-21.

2. Adler G. H. \& Tamarin R. H., 1984: Demography and reproduction in island and mainland white-footed mice (Peromyscus leucopus) in southeastern Massachussets. Can. J. Zool., 62: 58-64.

3. d'Agostino R. B. \& Pearson E. S., 1973: Tests for departure from normality. Empirical results for the distribution of ge and $g_{1}$. Biometrika, 60: 613-622.

4. Anderson P. K., 1961: Density, social structure and non-social environment in house-mouse populations and the implications for regulation of numbers. Trans. N. Y. Acad. Sci. (Ser. II), 23: 447-457.

5. Andrewartha H. G. \& Birch L. C., 1954: The distribution and abundance of animals. University of Chicago Press: 1-782. Chicago.

6. Andrzejewski R. \& Mazurkiewicz M., 1976: Abundance of food supply and size of bank voles home range. Acta theriol., 21: 237-256.

7. Andrzejewski R., Petrusewicz K. \& Waszkiewicz-Gliwicz J., 1967: The trappability of Clethrionomys glareolus (Schreber, 1780) and other ecological parameters obtained by the CMR recapture method. Ekol. pol. A, 15: 709-725.

8. Bergstedt B., 1965: Distribution, reproduction, growth and dynamics of the rodent species Clethrionomys glareolus (Schreber), Apodemus flavicollis (Melchior) and Apodemus sylvaticus (Linne) in southern Sweden. Oikos, 16: $132-160$.

9. Box G. E. P. \& Jenkins G. M., 1970: Times series analysis: forecasting and control. Holden Day, San Francisco.

10. Buchalczyk A., 1970: Reproduction, mortality and longevity of the bank vole under laboratory conditions. Acta theriol., 15: 153-176.

11. Bujalska G., 1970: Reproduction stabilizing elements in an island population of Clethrionomys glareolus (Schreber, 1780). Acta theriol., 15: 381-413.

12. Bujalska G., 1973: The role of spacing behaviour among females in the regulation of the reproduction in the bank vole. J. Reprod. Fert., Suppl., 19: $463-472$.

13. Bujalska G., 1975 a: Reproduction and mortality of the bank voles and the changes in the size of an island population. Acta theriol., 20: 41-56.

14. Bujalska G., $1975 \mathrm{~b}$ : The effect of supplementary food on some parameters in an island population of Clethrionomys glareolus (Schreber, 1780). Bull. Acad. pol. Sci. Cl. II, Ser. Sci. biol., 23: 23-28.

15. Bujalska B., 1981: Reproduction strategies in population of Microtus arvalis (Pall.) and Apodemus agrarius (Pall.) inhabiting farmland. Pol. ecol. Stud., 7: $229-243$.

16. Bujalska G., 1983: Reproduction. [In: "Ecology of the bank vole", Ed. K. Petrusewicz]. Acta theriol., 28, suppl. 1: 148-161.

17. Bujalska G., $1984 \mathrm{a}$ : Sex ratio in an island population of Clethrionomys glareolus (Schreber, 1780). Ann. Zool. Fennici.

18. Bujalska G., 1984 b: Population dynamics of an island population of Clethrionomys glareolus (Schreber, 1780). Ann. Zool. Fennici, 000: 000-000.

19. Bujalska G., 1985: Regulation of female maturation in Clethrionomys spp., with special reference to an island population of C. glareolus. Ann. Zool. Fennici, 000: 000-000.

20. Bujalska G., Andrzejewski R. \& Petrusewicz K., 1968: Productivity investi- 
gations of an island population of Clethrionomys glareolus (Schreber, 1780). II. Natality. Acta theriol., 17: 33-40.

21. Bujalska G. \& Janion S. M., 1981: Bank vole response to an increase of environmental capacity. Bull. Acad. pol., Ser. Sci. biol. Cl. II, 29: 129-133.

22. Bujalska G. \& Ryszkowski L., 1966: Estimation of the reproduction of the bank voles under field conditions. Acta theriol., 11: 351-361.

23. Charnov E. L. \& Finerty P., 1980: Vole population cycles: a case for kinselection. Oecologia (Ber1.), 45: 1-2.

24. Christian J. J., 1950: The adreno-pituarity system and population cycles in mammals. J. Mammal., 31: 247-259.

25. Christian J. J., 1955: Effect of population size on the weights of the reproductive organs of white mice. Am. J. Physiol., 181: 477-480.

26. Christian J. J., 1956: Adrenal and reproductive responses to population size in mice from freely growing population. Ecology, 37: 258-273.

27. Christian J. J., 1971: Population density and reproductive efficiency. Biol. Repr., 4: 248-294.

28. Christian J. J. \& Davis D. E., 1966: Adrenal glands in female voles (Microtus pennsylvanicus) as related to reproduction and population size. J. Mammal., 47: $1-18$.

29. Christian J. J., Lloyd A. A. \& Davis D. E., 1965: The role of endocrines in the self-regulation of mammalian populations. Recent. Progr. Horm. Res., 21: $501-568$.

30. Clarke J. R., 1955: Influence of numbers on reproduction and survival in two experimental vole populations. Proc. Roy. Soc. B, 144: 68-85.

31. Crew F. A. \& Mirskaia L., 1931: The effects of density on an adult mouse populations. Biol. Generalis, 7: 239-250.

32. Crowcroft P. \& Rowe F. P., 1957: The growth of confined colonies of the wild house mouse (Mus musculus L.). Proc. Zool. Soc. (London), 129: 359-370.

33. Finerty J. P., 1980: The population ecology of cycles in small mammals. Yale Univ. Press: 1-234. New Haven, London.

34. Fuller W. A., 1969: Changes in numbers of three species of small rodent near Great Slave Lake, N. W. T., Canada, 1964-67, and their significance for general population theory. Ann. Zool. Fenn., 6: 113-144.

35. Frank F., 1953: Untersuchungen über den Zusammenbruch von Feldmausplagen (Microtus arvalis Pallas). Zool. Jahrb. Jena, 82: 95-136.

36. Gebczyńska Z., 1983: Feeding habits. [In: "Ecology of the bank vole", Ed. K. Petrusewicz]. Acta theriol., 28, suppl. 1: 40-49.

37. Gliwicz J., 1975: Age structure and dynamics of numbers in an island population of bank vole. Acta theriol., 20: 57-69.

38. Gliwicz J., 1980: Island populations of rodents: their organization and functioning. Biol. Rev., 55: 109-138.

39. Gliwicz J., Andrzejewski R., Bujalska G. \& Petrusewicz K., 1968: Productivity investigation of an island population of Clethrionomys glareolus (Schreber, 1780). I. Dynamics of cohorts. Acta theriol., 13: 401-413.

40. Golikova V. L., 1958: Zametki po ekologii populacii lesnych myšej i ryžich polevok. Tr. nauč.-proizvod. Konf. Zašc. Rast. od Vred. i Boleznej na Jugo-vostoke, Saratov, 166-176.

41. Hansson L., 1978: Small mammal abundance in relation to environmental variables in three Swedish forest phases. Studia Forest. Suec., 147: 1-40. 
42. Hansson L., 1979: Food as limiting factor for small rodent numbers. Test of two hypothesis. Oecologia (Ber1.), 37: 297--314.

43. Hansson L., Löfqvist J. \& Nilsson A., 1978: Population fluctuations in insectivores and small rodents in northernmost Fennoscandia. Z. Saugetierkunde, 43: $75-92$.

44. Hoffmann R. S., 1958: The role of reproduction and mortality in population fluctuations of voles (Microtus). Ecol. Monogr., 28: 79-109.

45. Ivanter E. V., 1975: Populacjonnaja ekologija melkich mlekopitajuščich taežnogo severo-zapada SSSR. Izd. Nauka, Leningrad: $1-246$.

46. Ivanter E. V., 1981: Dinamika cislennosti [In: "Evropejskaja ryžaja polevka", Ed. N. V. Bashenina]. Izd. Nauka: 245-268. Moskva.

47. Jenkins G. M. \& Watts D. G., 1968: Spectral analysis and its applications. Holden-Day, San Francisco.

48. Jewell P. A., 1966: Breeding season and recruitments in some British mammals confined on small islands. Symp. Zool. Soc. London, 15: 89-116.

49. Jolly G. M., 1965: Explicit estimates from capture-recapture data with both death and dilution-stochastic model. Biometrika, 52: 225-247.

50. Kaczmarski F., 1966: Bioenergetics of pregnancy and lactation in the bank vole. Acta theriol., 11: 409-417.

51. Kaikusalo A., 1972: Population turnover and wintering of the bank vole, Clethrionomys glareolus (Schreber) in southern and central Finland. Ann. Zool. Fennici, 9: 219-224.

52. Kalela O., 1957: Regulation of reproduction rate in subarctic populations of the vole Clethrionomys rufocanus (Sund.). Ann. Acad. Sci. fenn., Ser. A, 4: 7-60.

53. Kalela O., 1962: On the fluctuations in the numbers of arctic and boreal small rodents as a problem of production biology. Ann. Acad. Sci. fenn., Ser. A. IV, 66: $1-38$.

54, Kalela O., 1971: Seasonal trends in the sex ratio of the greysided vole, Clethrionomys rufocanus (Sund.). Ann. Zool. Fennici, 8: 452-455.

55. Koshkina T. V., 1965: Plotnost' populacii i ee značenie $\mathrm{v}$ regulacii čislennosti krasnoj polevki. Bjul. Mosk. Obš̌. Isp. Prir., Otd. biol., 70: 5-19.

56. Koshkina T. V. \& Korotkov J. S., 1975: Regulatornyje adaptacji v populacijach krasnoj polevki v optimumie areala. Fauna i ekologija gryzunov, 12: 5-61. Izd. Mosk. Univ.

57. Krebs C. J., Keller B. L. \& Tamarin R. H., 1969: Microtus population biology: demographic changes in fluctuating populations of Microtus ochrogaster and M. pennsylvanicus in southern Indiana. Ecology, 50: 587-607.

58. Krebs C. J. \& Myers J. H., 1974: Population cycles in small mammals. Adv. Ecol. Res., 8: 267-399.

59. Lack D., 1954: The natural regulation of animal numbers. Oxford UniN. Press: 1-343. London.

60. Larsson T. B. \& Hansson L., 1977: Vole diet on experimentally managed afforestation areas in northern Sweden. Oikos, 28: 242-249.

61. Lidicker W. Z., Jr., 1978: Regulation of numbers in small mammal populations - historical reflections and a synthesis [In: "Populations of small mammals under natural conditions", Ed. D. P. Snyder]: 122-141.

62. Mazurkiewicz M., 1971: Shape, size and distribution of home ranges of Clethrionomys glareolus (Schreber, 1780). Acta theriol., 16: 23-60.

63. Murray B. G., Fr., 1982: On the meaning of density dependence. Oecologia (Berl.), 53: 370-373. 
64. Nicholson A. L., 1933: The balance of animal populations. J. Anim. Ecol., 2: $132-178$.

65. Nicholson A. J., 1954: An outline of the dynamics of animal populations. Austr. J. Zool., 2: 9-65.

66. Nikitina N. A. \& Merkova M. A., 1963: Ispolzowanie territorii myšami i polevkami po dannym mečenija. Bjul. Mosk. Obšc. Isp. Prir., Otd. biol., 48: $15-21$.

67. Obrtel R. \& Holišova V., 1974: Trophic niches of Apodemus flavicollis and Clethrionomys glareolus in a lowland forest. Acta Sc. Nat. Brno, 8: 1-37.

68. Petrusewicz K., 1966: Dynamics, organization and ecological structure of population. Ekol. pol. A., 14: 413-436.

69. Petrusewicz K., Andrzejewski R, Bujalska G. \& Gliwicz J., 1969: The role of spring, summer and autumn generation in the productivity of a free-living population of Clethrionomys glareolus (Schreber, 1780). [In: "Energy flow through small mammal populations", Eds. K. Petrusewicz \& L. Ryszkowski]. Państw. Wyd. Nauk.: 235-245. Warszawa.

70. Petrusewicz K., Bujalska G., Andrzejewski R. \& Gliwicz J., 1971: Productivity processes in an island population of Clethrionomys glareolus. Ann. Zool. Fennici, 8: 127-132.

71. Pitelka F. A., 1957: Some aspects of population structure in the short-term cycle of brown lemming in northern Alaska. Cold Spring Harbor Symp. quant. Biol., 22: 237-251.

72. Pitelka F. A. \& Schultz A. M., 1964: The nutrient-recovery hypothesis for arctic microtine cycles. [In: "Grazing in terrestrial and marine environments", Ed. D. J. Crisp]. Blackwell: 55-68. Oxford.

73. Popov V. A., 1960: Mlekopitajušcie Volzsko-Kamskogo kraja. Izd. AN SSSR, Kazanskij Filjal: 1-467, Kazan.

74. Pucek M., 1983: Habitat preference. [In: "Ecology of the bank vole", Ed. K. Petrusewicz]. Acta theriol., 28, suppl. 1: 31-40.

75. Rajska-Jurgiel E., 1976: Interactions between individuals of a population of the bank vole Clethrionomys glareolus (Schreber, 1780). Ekol. pol. A, 24: $3-35$.

76. Retzlaff E. G., 1983: Studies in population physiology with the albino mouse. Biol. Generalis, 14: 238-265.

77. Saitoh T., 1981: Control of female maturation in high density populations of the red-backed vole, Clethrionomys rufocanus bedfordiae. J. Anim. Ecol., 50: $79-87$.

78. Schultz A. M., 1969: A study of an ecosystem: the arctic tundra. [In: "The ecosystem concept in natural resource management", Ed. G. M. van Dyne]. Acad. Press: 77-93. New York.

79. Schwarz S. S., Pokrovski A. V., Istchenko V. G., Olenjev V. G., Ovtschinnikova N. A. \& Pjastolova O. A., 1963: Biological pecularities of seasonal generations of rodents with special reference to the problem of senescence in mammals. Acta theriol., 8: 11-43.

80. Siivonen L. \& Koskimies J., 1955: Population fluctuations and the lunar cycle. Pap. Game Res., Helsinki, 14: 1-22.

81. Smith H. S., 1935: The role of biotic factors in the determination of population density. J. Econ. Entomol., 28: 873-898.

82. Sokal R. R. \& Rohlf F. J., 1981: Biometry. The principles and practice of 
statistics in biological research (2-nd ed.) W. H. Freeman and Company: 1-859, San Francisco.

83. Solomon M. E., 1949: The natural control of animal populations. J. Anim. Ecol., 18: 1-35.

84. Southwick C. H., 1955: The population dynamics of confined house mice supplied with unlimited food. Ecology, 36: 212-225.

85. Stenseth N. C., 1977: Forecasting of rodent outbreaks: models and the real world. EPPO Bull., 7: 303-315.

86. Stenseth N. C., 1978: Energy balance and the Malthusian parameter, $\mathrm{m}$, of grazing small rodents. Oecologia (Berl.), 32: 37-55.

87. Strecker R. L. \& Emlen J. T., 1953: Regulatory mechanisms in house mouse populations - the effect of limited food supply on a confined population. Ecology, 34: 375-385.

88. Sviridenko P. A., 1967: Razmnoženie i kolebanie と̌islennosti ryžej polevki v uslovijach Ukrainy. Vest. Zool., 2: 9-24.

89. Taitt M. J. \& Krebs C. J. (in print): Population dynamics and cycles. [In: "Biology of the New World Microtus", Ed. R. H. Tamarin]:

90. Tanaka R., 1953: Home range and territories in the Clethrionomys population on a peat-bog grassland in Hokkaido. Bull. Kochi. Wom. Coll., 2: 10-20.

91. Thompson D. Q., 1955: The role of food and cover in population fluctuations of the brown lemming at Pt. Barrow, Alaska, Trans. 20th N. Am. Wildl. Conf., 166-176.

92. Thompson W. R., 1929: On natural control. Parasitology, 21: 269-281.

93. Traczyk H., 1965: Roślinność "Wyspy Dzikiej Jabłoni" na jeziorze Bełdańskim. Fragm florist. et geobot., 11: 541-545.

94. Traczyk H., 1971: Relation between productivity and structure of the herb layer in associations of "The Wild Apple Tree Island" (Masurian Lake district). Ekol. pol. A, 19: 333-363.

95. Viitala J., 1977: Social organization cyclic subarctic population of the voles Clethrionomys rufocanus (Sund.) and Microtus agrestis (L.). Ann. Zool. Fennici, 14: 53-93.

96. Viro P., 1974: Age structure in populations of the bank vole, Clethrionomys glareolus (Schreb., 1780), in Northern Finland. Aquilo, Ser. Zool., 15: 18-24.

97. Wiger R., 1982: Roles of self regulatory mechanisms in cyclic populations of C. glareolus: a hypothesis. Oikos, 38: 60-71.

98. White T. C. R., 1978: The importance of a relative shortage of food in animal ecology. Oecologia (Berl.), 33: 71-86.

99. Whittaker R. H., 1975: Communities and ecosystems (2nd ed). Mac MillanCollier: 1-385. New York, London.

100. Wynne-Edwards V. C., 1962: Animal dispersion in relation to social behaviour, Oliver and Boyd: 1-653. Edinburgh.

101. Zejda J., 1966: Litter size in Clethrionomys glareolus (Schreber, 1780). Zool. Listy, 15: 193-206.

102. Zejda J., 1976: The small mammal community of a lowland forest. Acta Sc. Nat. Brno, 10 (10): 1-39.

103. Zejda J., 1981: The small mammal community of a spruce monoculture. Acta Sc. Nat. Brno, 15 (4): 1-31.

104. Zeveloff S. J. \& Boyce M. S., 1980: Parental investment and mating system in mammals. Evolution, 34: 973-982.

Accepted, October 22, 1984. 
Gabriela BUJALSKA

\section{FLUKTUACJE LICZEBNOSCI WYSPOWEJ POPULACJI NORNICY RUDEJ W SWIETLE BADAN NAD JEJ ORGANIZACJA}

\section{Streszczenie}

Dwunastoletnie badania nad wyspową populacją Clethrionomys glareolus (Schreber, 1780) umożliwiły poznanie prawidłowości demograficznych, towarzyszących zmianom liczebności (Ryc. 1).

Rozkład liczebności populacji cechował się w kwietniu tendencją do wystąpienia skośności w prawo lub leptokurtozy, w czerwcu, wrześniu i październiku do skośności w prawo, a w lipcu do skośności w prawo i platykurtozy (Ryc. 2). Powyższe wyniki oraz analiza zmian wskaźnika fluktuacji liczebności stały się podstawą do wyróżnienia trzech okresów różniących się tempem przebiegu procesów populacyjnych: (1) Dynamicznego okresu kwiecień - lipiec, w którym następuje zmniejszanie się zakresu wahań liczebności populacji, (2) Inercyjnego okresu lipiec - poździernik, w którym utrzymany zostaje niewielki zakres fluktuacji liczebności i (3) również inercyjnego okresu październik - kwiecień roku następnego.

Brak migracji ogranicza istotne dla zmian liczebności populacji procesy do rozrodczości i śmiertelności. Scharakteryzowano zmiany rozrodczości potencjalnej, wyrażonej liczbą dojrzałych samic, ustabilizowaną w szerokim zakresie zmian liczebności populacji (Ryc. 3, równania (2) i (3)) oraz rozrodczości aktualnej, wyrażonej liczbą samic ciężarnych (Ryc. 4, równania (4), (5) i (6)).

Przeżywalność osobników w wieku do 6 tygodni (niełownych) była uzależniona do przeżywalności opiekujących się nimi samic i liczebności populacji (równania (7) i (8)). W drugiej części sezonu rozrodczego przeżywalność niełownej części populacji wyrażono jako funkcję liczebności populacji (równanie (9)). Przeżywalność części lownej (Ryc. 5) opisuje równanie (10), wiążące przeżywalność z liczebnością populacji. Niskie współczynniki korelacji w równaniach opisujących zależność przeżywalności różnych kategorii osobników od liczebności populacji wskazują, że przyczyn zmiennej przeżywalności szukać należy wśród innych niż gęstość populacji czynników.

Przeżywalność po zakończeniu sezonu rozrodczego (t.j. w okresie poździernik kwiecień), od której zależy wielkość stada podstawowego na wiosnę, stanowi funkcję liczebności populacji w październiku i temperatury w ostatniej dekadzie marca, wyznaczającej początek rozwoju wegetacji roślinnej (równanie (11)).

Funkcje porządkujące rozrodczość i przeżywalność względem liczebności populacji stały się podstawą budowy modelu empirycznego, symulującego zmiany liczebności populacji $w$ dwu pierwszych $z$ trzech wyróżnionych okresów roku (Ryc. 6 i 7, Tab. 1). Ostatni etap symulacji (w okresie trzecim, tj. październik - kwie-cień) przebiegal zgodnie z równaniem (11).

Dokonano najpierw symulacji deterministycznej dla trzech różnych stanów początkowych populacji (Ryc. 8). Po czterech latach od rozpoczęcia symulacji ustalił się wzorzec sezonowych zmian liczebności, identyczny dla trzech stanów początkowych. Wykazano podobieństwo między empirycznie obserwowanymi zmianami liczebności populacji a uzyskanymi w „stałym wzorcu" (Tab. 2). Następnie przeprowadzono dwie symulacje probabilistyczne (każda z nich dla 55 lat) przy założeniu, że: a) temperatura w ostatniej dekadzie marca zmienia się losowo i b) 
że zmienia się ona w cyklu 11-letnim (Ryc. 9). Wyniki uzyskane z symulacji porównano z wynikami empirycznymi pod względem charakterystyk rozkładu (Tab. 3, Tab. 5) oraz zakresu fluktuacji liczebności w kolejnych miesiącach badań (Ryc. 10). Wykazano duże podobieństwo między zmianami liczebności obserwowanymi empirycznie i uzyskanymi z symulacji.

Zbadano więc, czy symulowane zmiany liczebności wskazywać mogą na istnienie cyklu. Wykazano, że losowe zmiany temperatur wiosennych indukują wystąpienie cyklicznych zmian liczebności w lipcu (średnia długość cyklu około 2,6 roku) a zmieniające się w cyklu 11-letnim - 11-letni cykl liczebności w kwietniu (Ryc. 11) i ślad 11-letniego cyklu w lipcu (Ryc. 12).

Uzyskane wyniki przedyskutowano na tle współczesnych poglądów na demografię populacji. Zwrócono uwagę, że procesem stabilizującym liczebność populacji byla regulowana rozrodczość, a procesem destabilizującym liczebność - przeżywalność. Wysunięto hipotezę, że zmiany liczebności populacji nie zawsze muszą być interpretowane jako rezultat regulacji. Wydaje się to dotyczyć wszystkich populacji należących do tzw. K-strategów. 